Florida International University FIU Digital Commons

3-29-2011

\title{
Extended program notes for a recital of selected vocal literature
}

\author{
Kathleen Mary Bell \\ Florida International University
}

DOI: $10.25148 /$ etd.FI14050482

Follow this and additional works at: https://digitalcommons.fiu.edu/etd

Part of the Music Commons

\section{Recommended Citation}

Bell, Kathleen Mary, "Extended program notes for a recital of selected vocal literature" (2011). FIU Electronic Theses and Dissertations. 1468.

https://digitalcommons.fiu.edu/etd/1468 
FLORIDA INTERNATIONAL UNIVERSITY

Miami, Florida

EXTENDED PROGRAM NOTES FOR A RECITAL OF SELECTED VOCAL LITERATURE

A thesis submitted in partial fulfillment of the

requirements for the degree of

MASTER OF MUSIC

by

Kathleen Mary Bell

2011 
To: Dean Brian Schriner

College of Architecture and the Arts

This thesis, written by Kathleen Mary Bell, and entitled Extended Program Notes for a Recital of Selected Vocal Literature, having been approved in respect to style and intellectual content, is referred to you for judgment.

We have read this thesis and recommend that it be approved.
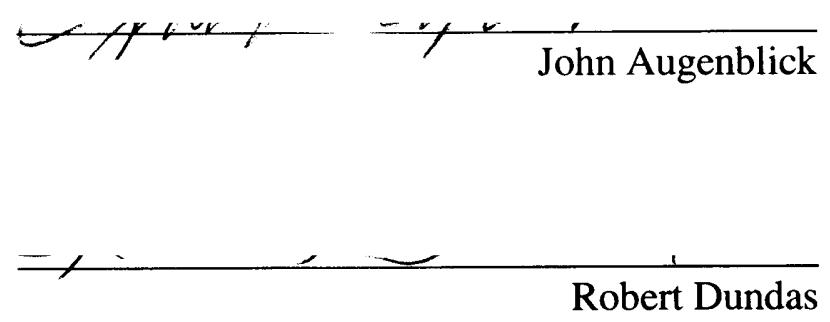

Date of Defense: March 29, 2011

The thesis of Kathleen Mary Bell is approved.

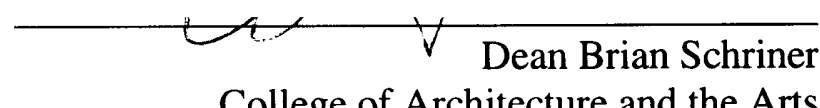

College of Architecture and the Arts

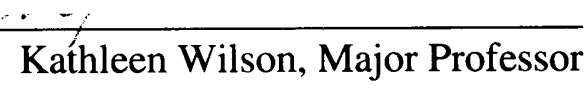




\section{ACKNOWLEDGMENTS}

I wish to thank the members of my committee for their patience, support and kindness. My major professor and mentor, Dr. Kathleen Wilson, in particular has been a source of inspiration as a teacher and human being. Her passion, integrity and knowledge of her field are unparalleled. I also would like to thank Dr. Joel Galand for his tremendous patience and deeply insightful comments and corrections on the manuscript. I am deeply humbled by and grateful for the talent and dedication of the professors in the Florida International University Music Department. I have found through the coursework and instruction that I am prepared more fully as a performer and teacher of singing. Finally, I wish to thank my family, friends, parish and students who have encouraged and inspired me throughout this whole process. 


\section{ABSTRACT OF THE THESIS \\ EXTENDED PROGRAM NOTES FOR A RECITAL OF SELECTED VOCAL}

LITERATURE

by

Kathleen Mary Bell

Florida International University, 2011

Miami, Florida

Professor Kathleen Wilson, Major Professor

The purpose of these extended program notes is to provide information that will assist the listening audience in comprehending the historical and biographical significance of the each vocal selection. A brief analysis of each selection, a historical interpretation of the work, a translation of the texts and a $\mathrm{CD}$ of the recital are included. The contents of the recital comprise of several selections from the soprano repertoire: The Georg Phillip Telemann cantata Lauter Wonne, lauter Freude; the Wolfgang Amadeus Mozart Laudate Dominum from the Vesperae solemnes de confessore; the Joaquín Nin y Castellano Diez Villancicos de Noël; Gabriel Fauré's art songs Dans le ruines d'une abbay, Les Berceaux, and Au bord e l'eau; Sergei Rachmaninov's three songs Oni otvechali, Zdes Khorosho, and Vocalise; and Libby Larsen's Cowboy Songs. 


\section{TABLE OF CONTENTS}

CHAPTER

PAGE

INTRODUCTION. 1

I. Georg Philip Telemann: Lauter Wonne, lauter Fruede.......................2

II. Wolfgang Amadeus Mozart: Laudate Dominum from Vespere Solennes.....10 de Confessore

III. Joaquin Nín y Castellanos: Diez Villancicos de Noël........................12

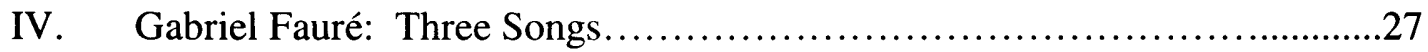

V. Sergei Rachmaninov: Three Songs.....................................33

VII. Libby Larsen: Cowboy Songs.......................................39

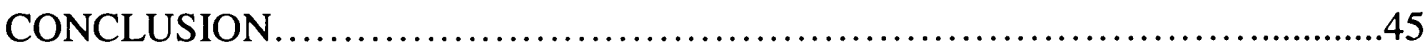

LIST OF REFERENCES ...........................................................

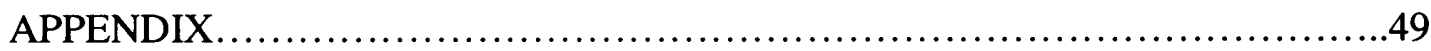




\section{LIST OF FIGURES}

FIGURE

PAGE

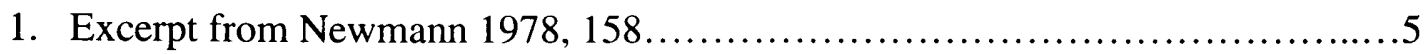

2. Lauter Wonne, lauter Freude: flute and voice part, $\mathrm{mm} .10-15 \ldots \ldots \ldots \ldots \ldots \ldots 6$

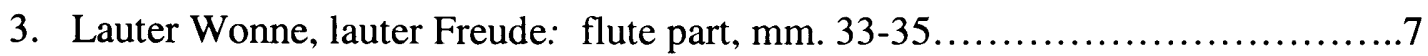

4. Ein stetes Zagen: flute and voice part, $\mathrm{mm} .10-17 \ldots \ldots \ldots \ldots \ldots \ldots \ldots \ldots \ldots \ldots$

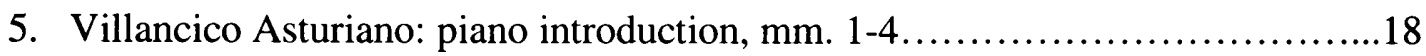

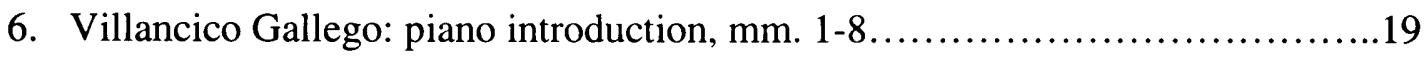

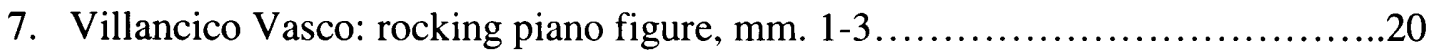

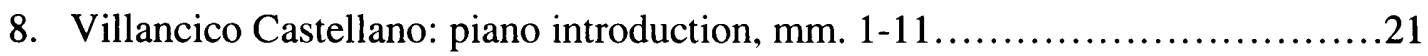

9. Villancico de Cordoba: piano introduction, mm.1-9.......................22

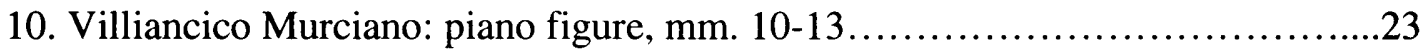

11. Jesús de Nazareth: Ay! Vocal motive: mm. 1-10...........................25

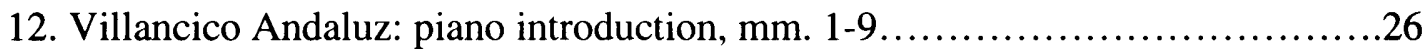

13. Les Berceaux: piano introduction with rocking rhythm, mm. $1-2 \ldots \ldots \ldots \ldots \ldots . . .31$

14. Oni otvechali: vocal part with the last answer, mm. $18-24 \ldots \ldots \ldots \ldots \ldots \ldots \ldots . \ldots 36$

15. Vocalise: voice and piano counterpoint, $\mathrm{mm} .33-35 \ldots \ldots \ldots \ldots \ldots \ldots \ldots \ldots \ldots$

16. Bucking Bronco: example of text painting, $\mathrm{mm} .11-12 \ldots \ldots \ldots \ldots \ldots \ldots \ldots \ldots . . \ldots \ldots 1$

17. Bucking Bronco: piano rhythmic figure, $17-18 \ldots \ldots \ldots \ldots \ldots \ldots \ldots \ldots \ldots \ldots \ldots 42$

18. Lift Up To Heaven: vocal text paining, mm. $7-8 \ldots \ldots \ldots \ldots \ldots \ldots \ldots \ldots \ldots \ldots . \ldots \ldots$

19. Billy the Kid: Shortnin' Bread quotation in piano accompaniment: mm. 1-3...43

20. Billy the Kid: text painting of the word rage with ossia, mm. 10-11 ...........44

21. Billy the Kid: Return of Shortnin' Bread quotation, mm. 17-21 ...............45 


\section{INTRODUCTION}

This voice recital was given in partial fulfillment of the requirements for the Master of Music degree in Vocal Performance. The recital was performed on Tuesday, March 29, 2011 in the Wertheim Performing Arts Center Instrumental Hall at 8:00 PM. A brief biography of each composer, analysis, interpretation and translations of each selection as well as an accompanying $\mathrm{CD}$ are included. 


\section{Georg Philipp Telemann: Lauter Wonne, lauter Freude}

Telemann originally scored his cantata Lauter Wonne, lauter Freude for high voice, alto recorder and basso continuo. In this recital the cantata will be performed by high voice, transverse flute and piano. The extremely prolific composer published it at the height of his career as part of a cycle of seventy-two solo cantatas titled Harmonischer Gottesdienst (Hamburg, 1725-26). The author, Matthäus Arnold Wilkens (1704-1759), based the text of Lauter Wonne on the fourth chapter of the Epistle to the Philippians, verses 4-9 (Whybrow 2009, 1). It was written to be performed on the fourth Sunday of Advent.

Georg Phillip Telemann, born in Magdelburg, Germany on March 14, 1681 was widely regarded as "Germany's leading composer in the early and middle $18^{\text {th }}$ Century...an important link between the late Baroque and the new Classical style" (Ruhnke 1985, 281). Although there is no definitive count of the number of works this self-taught musician composed, it is widely accepted that he composed some 1,500 sacred cantatas. He composed at least 3,000 works (half of them lost) in every genre and style of his day. Unconstrained by a formal musical education, he learned by studying the scores of great masters.

Telemann was instrumental in transforming German musical life. He had served in several important musical posts when, at the age of forty, he won his most significant position. In July, 1721, the city of Hamburg offered him the prestigious post of Kantor of the Johanneum, a post which also involved the musical directorship of the five main churches in the city. His duties included composing two cantatas a week, producing a new Passion annually, as well as providing masses and incidental music for numerous 
other feast days and liturgies. Although his post was limited to the composition of sacred music, the industrious Telemann also became involved with the Hamburg Opera. This was remarkable because “ $[u]$ ntil the $18^{\text {th }}$ century a composer's output was largely dictated by the nature of the post he held, and the various spheres of musical activity were strictly defined. Telemann refused to be fettered, as a composer, by the chains of his official duties; and he broke down the barriers between sacred and secular music" (Ruhnke 1985, 295). The Hamburg city fathers tried to force him to refuse the position of director of the Hamburg Opera. In response, Telemann applied and was awarded another position in Leipzig. In the end, the city fathers refused to release him from his contract. The ending result was an increase in salary and that they cease their objections to his participation with the Hamburg Opera.

Telemann organized public concerts of both his sacred and secular works. He was also one of the first musicians who published his own musical compositions, engraving them himself. Telemann was a very wealthy and highly respected man in his day. Publishing music and producing public concerts was prompted more by a desire to help his fellow man enjoy good secular and sacred music than for monetary considerations. He paved the way for musicians to have artistic control over the publication and performance of their own music, which was unprecedented in eighteenth century Germany. Additionally, he was very influential on the young musicians surrounding him. "Even in his youth...he inspired and stimulated the most gifted music lovers among his fellow students to become professional musicians” (Ruhnke 1985, 297).

Telemann's cantatas were extremely popular in his day because they were practical and musically fashionable, tuneful and relatively easy to play. Each cantata in the 
Harmonischer Gottesdienst was originally published individually so that it might be performed in other churches as well as private homes. All of the cantatas are scored for solo voice, solo obbligato instrument and basso continuo. During the Baroque period obbligato referred to an essential instrumental part that was fully written out. The basso continuo consisted of a notated bass line entrusted to a low instrument (e.g., the viola da gamba), supplemented with a keyboard part that fleshed out this bass line into a full chordal accompaniment. This accompaniment was more-or-less partially improvised; sometimes, the composer provided figures to indicate how he wanted his bass line realized and sometimes he merely provided an unfigured bass. This sparse instrumentation allowed these cantatas to be used for either private devotions or as the second cantata after the sermon, when the majority of paid musicians would have already left for another performance. These cantatas, all of them based on the Epistle reading for that Sunday. consist of two da capo arias with an intervening recitative. A da capo aria was one that was comprised of three sections: (A); a central section (B), often contrasting in mode and emotional affect; and a repeat of the A section. The texts are poetic paraphrases of Scripture, rather than exact quotations.

"In the forward of his Harmonischer Gottesdienst Telemann elaborates on various aspects of performance practice. He goes into great detail about how to treat the voice in the recitatives and demonstrates by many examples in the music that the notation often deviates considerably from the desired performance. This concerns in particular the last two notes before rests, but transition notes [i.e., passing tones] and suspensions can nevertheless be inserted in other places" (Whybrow, 2009). 


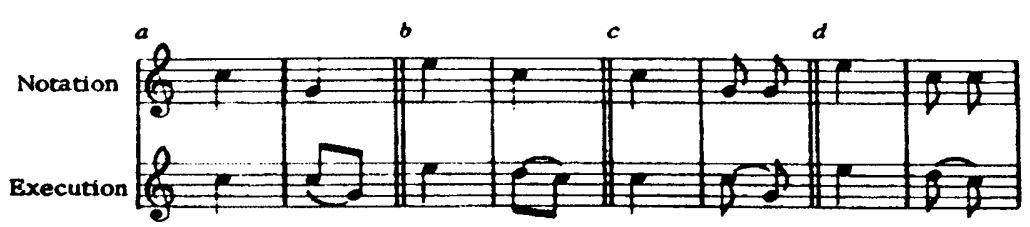

Ex. 16.52. Telemann's Recitative Formulas

Figure 1 Excerpt from Newmann 1978, 158

In the Lutheran liturgy, Philippians 4:4-9, the epistle on which the cantata's text is based, is read on the fourth Sunday of Advent.

Rejoice in the Lord always. I shall say it again: rejoice! Your kindness should be known to all. The Lord is near. Have no anxiety at all, but in everything, by prayer and petition, with thanksgiving, make your requests known to God. Then the peace of God that surpasses all understanding will guard your hearts and minds in Christ Jesus. Finally, brothers, whatever is true, whatever is honorable, whatever is just, whatever is pure, whatever is lovely, whatever is gracious, if here is any excellence and if there is anything worthy of praise, think about these things. Keep on doing what you have learned and received and heard and seen in me. Then the God of peace will be with you (New American Standard Bible).

- The text of "Lauter Wonne, lauter Freude spielt in meiner regen Brust" is translated as "Sheer (or pure) bliss, sheer (or pure) joy, plays in my stirred breast" depicts the uplifting character of Advent, the period of waiting for the coming of the Christ child. The Aria is marked vivace and is in 6/8 time, in the style of a gigue. During the A section of this da capo form, set in the bright key of $\mathrm{G}$ major, Telemann uses repeated $32^{\text {nd }}$ note embellishments sequentially in both the voice and obbligato part every time the singer sings "regen" evoking the image of a "stirred" heart. 

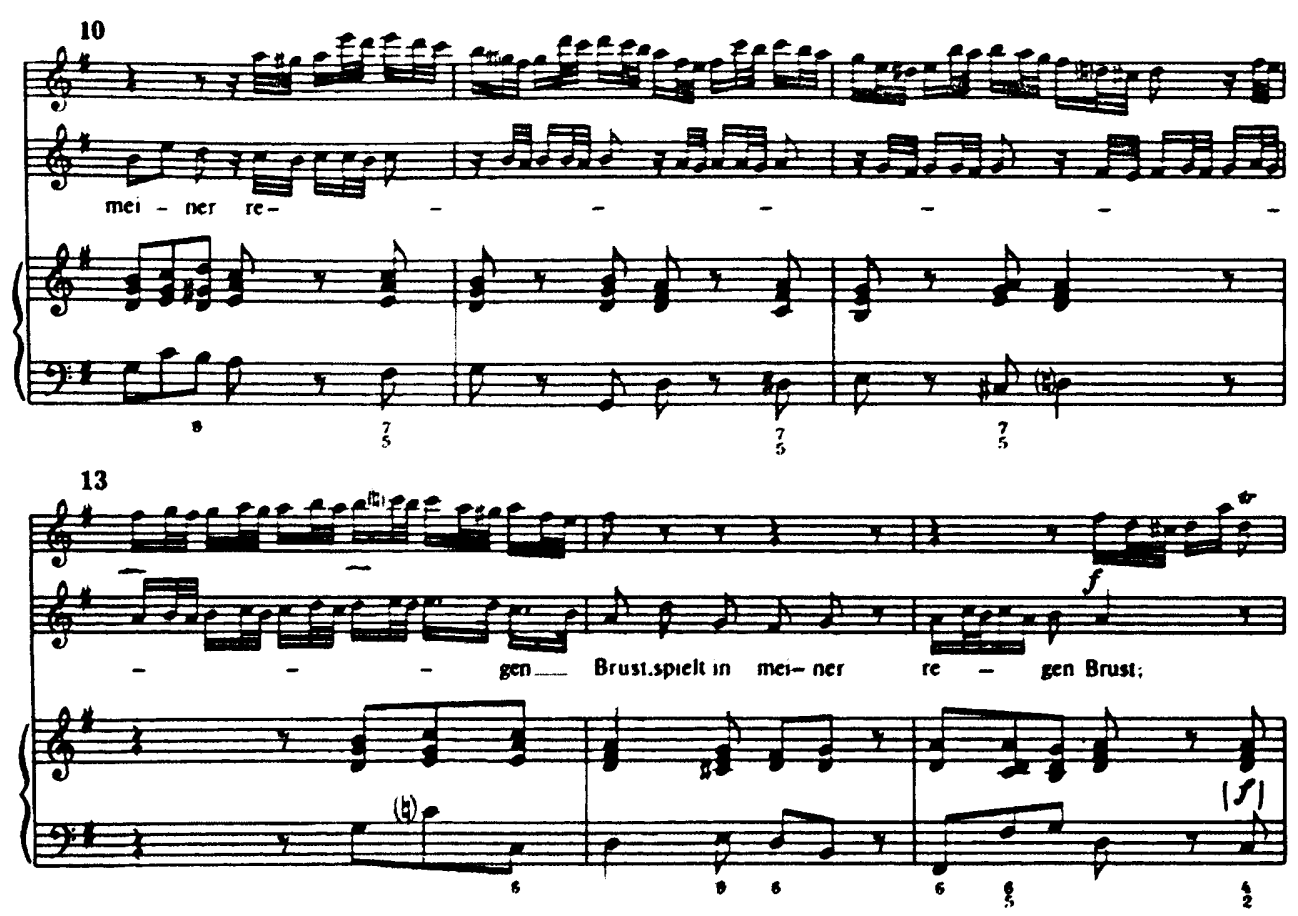

Figure 2 Lauter Wonne, lauter Freude: flute and voice part, mm. 10-15.

In the B section, which is written in the style of a siciliano or pastorale, the text exhorts the listener to find desire only in God and not worldly vanities. The vocal line is simply set while the obbligato stirs with florid thirty-second note melismatic passages from the A section. These passages are juxtaposed to what is expressed in the text as a "desire for God" and the "flaming breast." The only text that is repeated is that of Gott allein ist seine Lust (God alone is their desire). It is sung three times, a Judeo-Christian literary tradition to emphasize the superlative nature of living a life where God alone is their source of desire. 


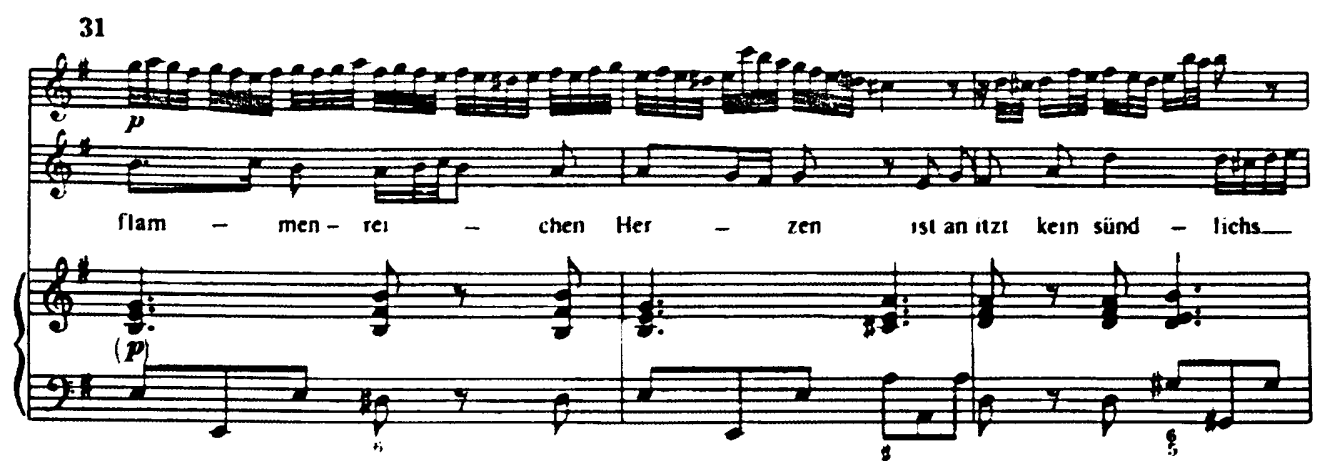

Figure 3 Lauter Wonne, lauter Freude: flute part, mm. 33-35.

The recitative casts a shadow on the joyful anticipation of the first movement; it describes those who refuse to relinquish the "Scherzen einer eitlen Gluht" ("pleasures of idle fancy") alluded to in the Aria. The recitative text cites several pitfalls: chasing after pleasure, money and possessions, high honor, revenge and further unspecified earthly things. The recitative concludes with an allusion to Ecclesiastes: all things pass away and only those who find pleasure in God will experience true joy and salvation. The tessitura of the recitative is very high and rests in the upper passaggio of $\mathrm{e}^{2}$ to $\mathrm{g}^{2}$ and the tonality centers around the dominant.

The second aria begins in G minor, depicting the text which talks of "constant trembling, an eternal gnawing" ("ein stetes Zagen, ein ewigs Nagen") that awaits those who laugh about the Christian faith. The tempo is in the style of a slow sarabande, with its $3 / 4$ time signature and emphasis on beat two. With the word beschließet, the tonality switches to $B^{b}$ major and the tempo increases, suggesting a stylistic shift from a sarabande to a courante, which is a lively dance in three quarter time characterized stepwise passagio. Telemann depicts the word lachen (laughing) with four repeated staccato eighth notes on $\mathrm{d}^{2}$, followed by a four sixteenth note turn that oscillates between 
major and minor tonic chords. After the word, Welt (world), the stately sarabande tempo returns, this time in $B^{b}$ major, but quickly move to $G$ minor via a series of secondary dominants all leading to the laughter that this time is represented by the same tempo change from sarabande to courante and by repeated octave leaps $\left(\mathrm{g}^{3}\right.$ to $\left.\mathrm{g}^{2}\right)$ in the vocal part. The flute obligato now takes up the motive of four sixteenth-note turns.
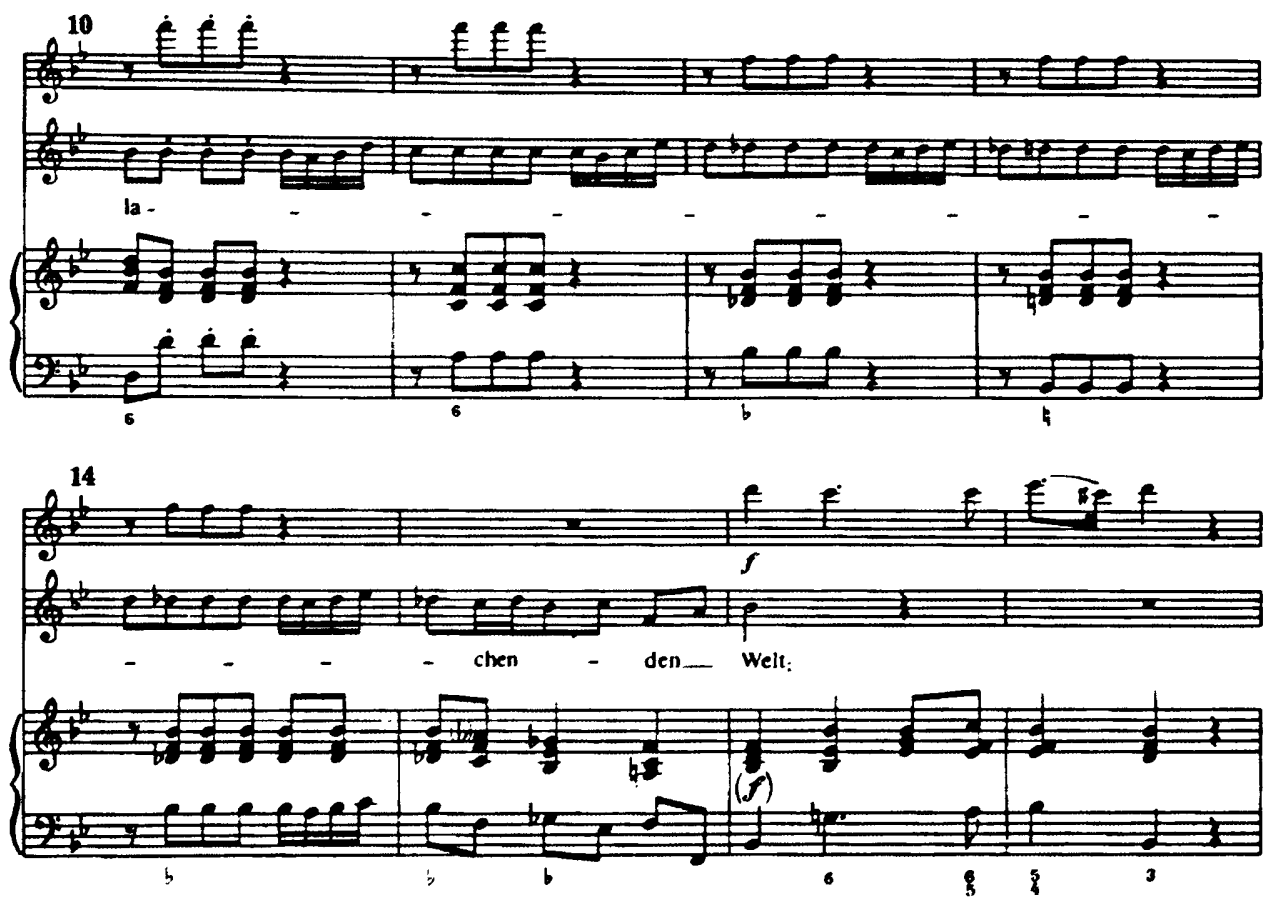

Figure 4 Ein stetes Zagen: flute and voice part, mm.10-17.

The B section is in G major and alludes topically to the Italian corriente, since it is in a somewhat faster $3 / 4$ time. Here the text speaks of the delights and everlasting pleasure of those who seek joy in God. The text setting is straight forward with ewig (forever) being repeated several times to emphasize that this joy in God is everlasting.

Lauter Wonne, Lauter Freude, as with all the cantatas from the Harmonischer Gottesdienst, demonstrates the aesthetics of style of the late German Baroque period. According to the two leading music theorists of his day, Johann Scheibe (1708-1776) and 
Johann Mattheson (1681-1764), "church music should aim to arouse the emotions in a specific way and to interpret the finer points of the text dramatically. To achieve this, the most appropriate style was that of the theatre, for even in church we are only human beings, susceptible to human representations... sacred music demanded an elevated style the more vividly to bring out the imager and 'affect' of the text" (Ruhnke 1985, 300). Telemann was a master of depicting the text, treating the words "stirred" and "laughter" dramatically and treating the concepts of joy in God with soaring lines. An analysis of Telemann's music provides evidence that its quality is just as impressive as its quantity. 
II. Wolfgang Amadeus Mozart: Laudate Dominum from Vesperae solemnes de confessore

Laudate Dominum is the fifth section of the Vesperae solemnes de confessore, K.339 composed by Wolfgang Amadeus Mozart in 1780 for the Salzburg Cathedral. The text is the traditional Latin text based on Psalm 117from the Vulgate, which is the fourth century, authorized Roman Catholic Translation of the Bible. Vespers, which is celebrated at sunset, is the seventh canonical office, or time of prayer; its principle elements are drawn from the Psalms, the Magnificat canticle and their antiphons. Among the many criteria for a Solemn Vespers, all Psalms, antiphons and canticles must be sung during the service This indicates that K339 was most likely composed for a Festum Pallii or an important feast day, however, there is no record of a performance at the Cathedral.

Although Mozart had been granted a coveted church position, 1780 was a time of personal unrest for him fueled by his mother's death in 1778 , the unrequited love of Aloysia Weber and the restrictions that Archbishop Hieronymous von Colloredo of Salzburg imposed on his music. Mozart considered these restrictions demeaning, although in his insistence that the music needed to be concise, brief, and subservient to the liturgy, Colloredo was merely enacting in Salzburg the more modern, enlightened approach to liturgy that the Josephinian reforms were effecting in Vienna. More specifically, liturgical music needed to be earnest and church-like, with stricter contrapuntal procedures in order to aspire to "higher goals" (Albert 2007, 566). Mozart was a musical prodigy and able to adapt to any style. He viewed composing almost like 
breathing, being in a state of constant inspiration. "Artistic creativity constituted the true meaning of Mozart's life and, as a result, was also his destiny” (Albert 2007, 566).

As part of his duties to the Court of Salzburg, Mozart wrote two settings of the Vespers psalms. Laudate Dominum derives from the second and better known setting. The Vesperae Solemnes ranks among Mozart's most enduring church compositions. He was particularly proud of this work and asked that his father send it to Gottfried Van Sweten, an Austrian patron of the arts. In accordance with the Archbishop's requirements, Mozart sets the long texts simply with little verbal repetition. The music alternates between solo sections and four-part homophony. In addition, the key scheme is limited to tonic ( $\mathrm{F}$ major), dominant (C Major), subdominant $\left(\mathrm{B}^{\mathrm{b}}\right.$ major).

The meter of Laudate Dominum is in 6/8 time and has markedly less pronounced virtuosic features than his other vocal works. The graceful floating vocal line seems to emerge out of the piano melody. The vocal range $\left(d^{1}\right.$ to $\left.f^{2}\right)$ and the tessitura is modest. The Laudate Dominum was originally scored for Soprano solo, SATB choir, and orchestra. For this recital it will be performed with soprano voice and piano. The ending “Amen" displays the soprano's soaring legato line, albeit with understated elegance. In Laudate Dominim the words of the psalmist, "Praise the LORD, all you nations! Give glory, all you peoples! The LORD'S love for us is strong; the LORD is faithful forever. Hallelujah!” (New American Standard Bible) are realized. 


\section{Joaquín Nin y Castellanos: Diez Villancicos de Noël}

A villancico is a variety of Spanish secular pastoral or love poetry from the second half of the $15^{\text {th }}$ century set to music as a popular song. In the late $16^{\text {th }}$ century the sacred villancico began to dominate. These works were frequently performed in services and processions at Christmas, Corpus Christi and other feast days. This was the main way of explaining the Gospel and the stories of the main feasts, since the majority of the populace was illiterate. Although in modern times the villancico has come to mean Christmas carol, the more accurate title would be Villancico de Noël. The main themes of the villancico include 1) the person of the Christ Child, 2) the Nativity at Bethlehem, 3) the divinity of the child, and 4) the purpose of his birth: redemption. There is often a reference to the two animals: the "mula y buey" (mule and ox) and a cave or stable being referred to as a "portal" or archway.

Traditionally there is a thematic insistence of the "cold," because of the traditional celebration of Christmas on the $25^{\text {th }}$ of December in the villancicos. The villancicos also depict the poverty and hardship of Bethlehem, which was also common in Spain at that time. There is often someone asking for shelter from the cold. The journey to Bethlehem is considered allegorically as the progress of the sinner to God, only with the help of the Christ Child. The human nature of Christ is often referred to as a garment. The main purpose of the villancico seems to be to connect the nativity of Christ with that of His Passion. His death is the very purpose of his birth. Another common theme is one of praising Mary due to her position as Mother of God, for Mary's name is the symbol of all happiness just as she is its source. 
Diez Villancicos de Noël are based on popular folk themes from ten different regions of Spain. Folk music is music that seems to be the natural and instinctive expression of the people, one that is not influenced by scholastic elaboration. The music is handed down orally creating a collective tune because it undergoes changes with each retelling. Since each selection hails from a different region of Spain, Nin takes us on a virtual musical tour of the country.

Before commencing a musical tour of the regions of Spain, it is important to discuss the composer, piano virtuoso and musicologist Joaquín Nin y Castellanos. Although Nin was born in Cuba, he is considered to be the first Spanish nationalist composer for several reasons: Nin was born in Havana while it was still a Spanish colony, he spent most of his life in Europe, his education was Spanish and he composed Spanish folk music, not Cuban folk music (Marco 1993, 62). In 1902, Nin moved to Paris to study piano and composition with Mozkowski at the Schola Cantorum. He made his professional piano debut in Paris in 1904 presenting the works of Charbonnieres, Couperin and Rameau. Nin was a passionate proponent of Baroque piano composers, most especially Father Antonio Soler, who has been considered the most gifted of Spanish eighteenth century composers (Kimball, p.507). Since Nin was the main proponent of the music of Father Soler, who had studied with Domenico Scarlatti, Nin, like many modern Spanish composers was also greatly influenced by the music of Domenico Scarlatti. Nin arranged two volumes titled Classiques Espagnols du Piano that consisted of piano pieces by Soler and his contemporaries, who were mostly clerics and Catalans. Nin helped bring about the latter day renaissance of Spanish music through his skillful and sensitive 
arrangements of songs and keyboard pieces of the past (Marco 1993, 62). He became a piano professor in 1906. In 1909, the same year that he published his first book Pro Arte that dealt with the aesthetics of music, he returned to Cuba in what would be a failed attempt to create a national conservatory.

Nin was a leading member of the elite group of Spanish musicians living in Paris which included Albéniz, Granados, de Falla, Turina and the pianist Ricardo Viñes. Paris, at the beginning of the twentieth century, was the center of intense musical and artistic activity. A great majority of $20^{\text {th }}$ Century Spanish composers gathered there to be inspired, compose and eventually be published for the first time. As part of his "mission," he promoted the idea that "Art" required a renunciation of the self. He was more concerned with serving the music than the audience. Nin believed that the two main musical ills of his time were commercialism and virtuosity. Nin believed that the art of interpretation should be a sort of priesthood. His second publication Idées et Commentaires was devoted to fighting egoism in art.

Nin's knowledge and enthusiasm for the folksongs of his adopted mother country, Spain, knew no bounds. His arrangements are characterized by melodic charm, rhythmic vitality and folksy warmth. In 1923, along with Maria Barrientos, he premiered several songs from the Spanish repertoire of the $18^{\text {th }}$ century, some of his arrangements for several folk songs and five old Spanish tonadillas from the $18^{\text {th }}$ century. Adolfo Salazar wrote of his Canciones populares españolas, "Joaquín Nin had won an enviable reputation as a specialist of the old classics, of the oldest, most forgotten classics" (Marco 2993, 60). Since Nin was a virtuoso pianist, his folksong arrangements reflect his very 
individual pianism and are carefully annotated. He considered the villancicos to be stylizations, not transcriptions or even harmonizations, but melodies for voice and piano that utilized folk themes. He indicates that prudence is required and that "the instrumental accompaniment of the Spanish folk song has its requirements and we could say, its technical traditions, not at all scholastic, but with an evident charm" (Cockburn 1992, 116).

In Paris Nin's musical and intellectual life thrived, but his familial life suffered. Joaquín had married for money. His wife Rosa was from an aristocratic, wealthy Danish family in Cuba. At first the marriage seemed to work as he was extremely narcissistic and Rosa was dedicated to his career. However, Nin family life soon consisted of constant financial troubles, a general disdain for his young children, frequent beatings and inappropriate pictures. The only physical and emotional intimacy with his famous literary daughter, Anaïs Nin, took place under ritual punishment or pornographic photo sessions. In 1912, Nin, who has been described as a philandering, abusive and immature man who made no secret of his sexual adventures, sent his wife and children to live with his parents in Barcelona and abandoned his family forever. In 1914, Rosa set sail with her children for New York to start a new life.

Once his family was out of the picture Nin lived like a prince in the elegant suburb of St. Cloud. He kept a salon that vied with that of Albéniz as a milieu where the best of Parisian musical society could be met. Nin was a colorful and controversial character, whose aristocratic bearing won him a place in the highest levels of society. He had the artist's nature, a love of music and aesthetics. He was a perfectionist, but did not believe 
perfection was actually attainable. He strove for mastery and control over his life, but he was aware of its destructiveness and how close we all are to death at any moment. This mindset gave him a keen sense of the absurd. A self-proclaimed realist, Nin believed in power and in lust, espousing that these so called virtues elevated one to a spiritual plane and lifted us from the physical.

Diez Villancicos de Noël was composed by Joaquín Nin y Castellanos from 1932 to 1933. There is one very interesting aspect of his life that is not found in your usual biography: his relationship with his daughter, diarist, actress and author Anaïs Nin. The composer had had virtually no relationship with his first family for the better part of twenty years. In 1932, under the advice of her therapist Anaiis began to correspond with her father. She was obsessed with the abandonment and desperately wanted to connect with her father. Nin searched for a "soul love" in his daughter, not merely a physical love. He thought this soul love would replace institutional religion, give us power and in the end liberate us. With her therapist's approval, Anaïs planned to seduce her father and then abandon him just as he had abandoned her as a little girl. In 1933, father and daughter were lovers for 9 days and then she did in fact abandon him. It was during these two personally eventful years that he composed these highly religious folk songs. The author has indicated the year of composition for each one, for perhaps a correlation can be drawn between their composition, the consummation of this relationship and its ultimate demise.

It is with this beneath our consciousness that our tour of Spain through the artistic vision of Joaquín Nin y Castellanos begins. Spain has been called by Ortega y Gasset, the 
Spanish Liberal philosopher, not a nation, but a series of watertight compartments, since most are divided by either rivers or mountain ranges. Each region of Spain retains a completely individualistic concept of itself with its own traditional dances, folk music and in many cases language. Many villagers only speak the language of their region until they begin formal scholastic studies where Castillian is taught. There seems to be many explanations for this regional isolationism according to Gilbert Chase (Chase 1959, 15). He cites the natural barriers of rivers and mountains that divide the country. He also believes the Spaniard to be a stubborn individualist, the strongest being that of the Catalán, the land of Nin's father. Spanish folk music is amongst the richest in the world partly due to the many cultures that have mingled in the Iberian peninsula, most importantly the Celts, Jews and Arabs.

Nin begins with Asturias in the northwest portion of Spain closest to France. This was the first Christian kingdom on the Iberian Peninsula and since it rains has a lush green landscape. When describing the folk music of Northern Spain which includes Asturias, Galicia, the Basque provinces and Catalonia, Nin states that "things are different, rhythm grows calm, widens up, ceases to shake and has a certain majesty, then gives way to the song in its noblest and purest meaning" (Cockburn 1992, 117). This villancico was composed in 1932 and contains a stately walking rhythm of the piano introduction. The first line of the carol states that nothing can compare with a walk at one to see the Child in the cradle. The poetry is representative of the standard villancico with its reference to the child in the cradle and the remembrance of the meaning of his 
birth, the shedding of his blood. Could Nin have placed this one first because he felt he was in need of redemption?

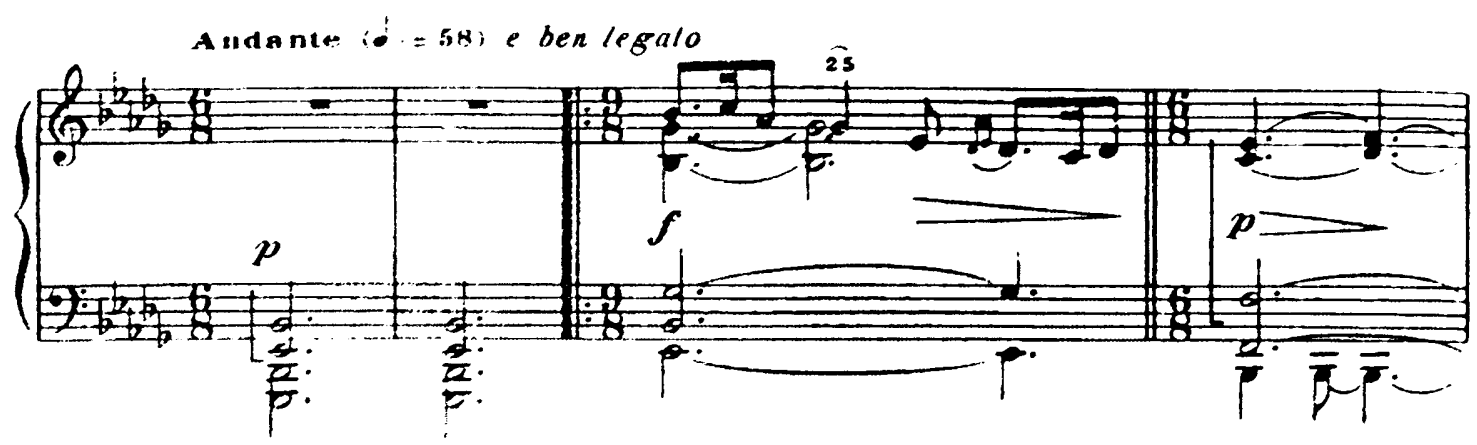

Figure 5 Villancico Asturiano: piano introduction, mm. 1-4.

The second villancico, also composed in 1932 and being one of two of his villancicos not taken from a popular theme, takes us to Spain's extreme Northwestern corner, to the land of Galicia. Galicia is most famous for its pilgrimage to the Shrine of Santiago de Compostela. St. James the elder is the patron saint of Spain, the first supposedly to preach the Gospel in Spain. This carol is also composed in 1932. The language of the people of this region and this villancico is Gallego. Gallego and Portuguese in medieval times were a single language. Although this carol retains a stately nature, the rhythm is a precursor to flamenco, which one can hear in the first lines of the voice part in $6 / 8$ time and the dotted eighth note followed by a sixteenth note and then four eighth notes pattern. This measure is then followed by a $3 / 4$ bar with equal quarter notes. This villancico also has another typical feature in that there are two verses with repeated refrain. 

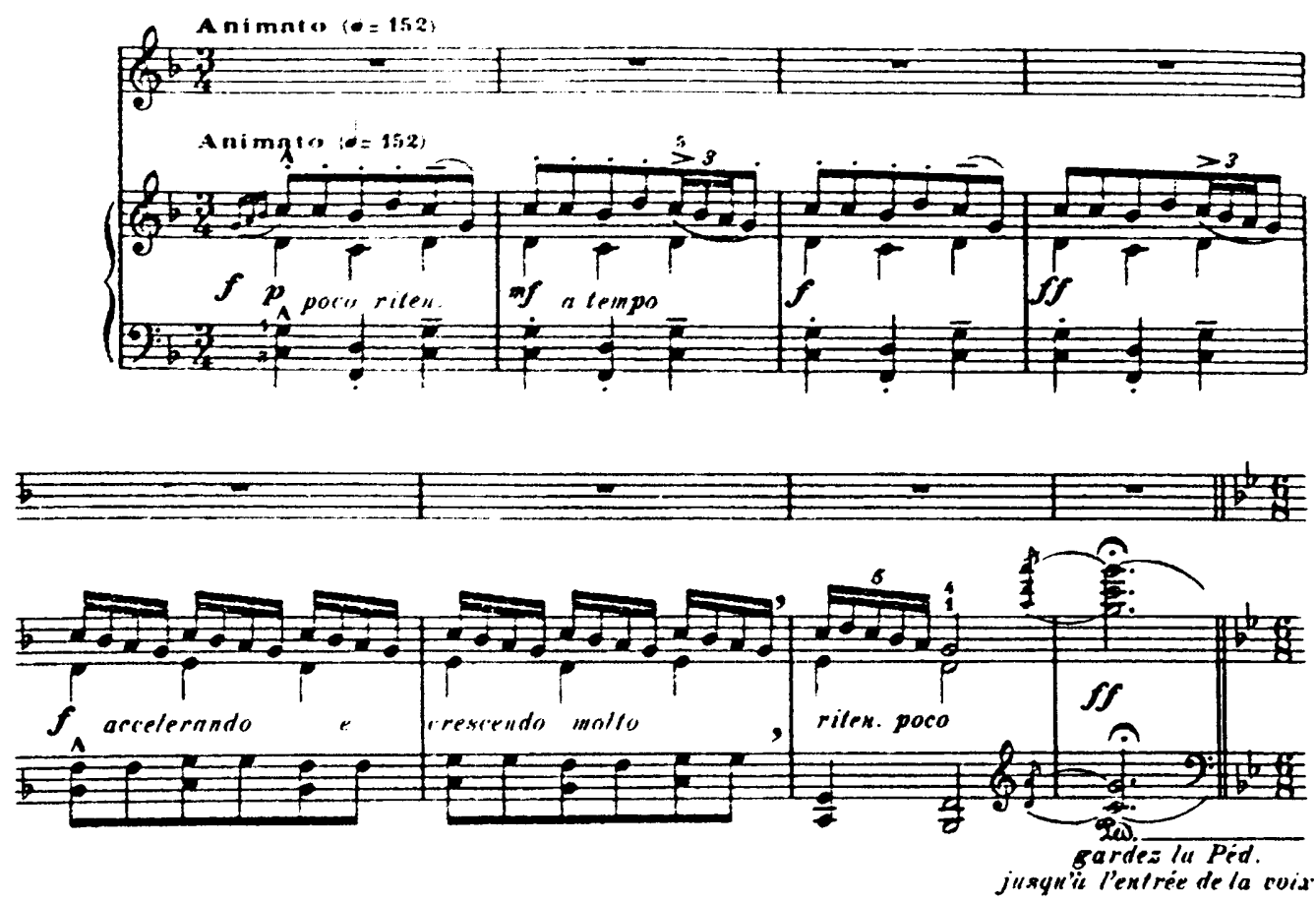

Figure 6 Villancico Gallego: piano introduction, mm. 1-8.

The third villancico, also composed in 1932, utilizes a popular tune from the Basque Region, in the north central part of Spain. The carol is sung in Basque or Euskera, which is considered a genetic language isolate, one that has not been demonstrated to be descended from an ancestor common to another language. Like the Basque people whose foremost value is that of the family, this villancico is a lullaby and the subject matter is not of the Christ child, but how we will celebrate as a family Christmas Eve. The accompaniment represents the rocking of the cradle with its eighth note, quarter note, eighth note quarter note repeated pattern in 6/8/time. 


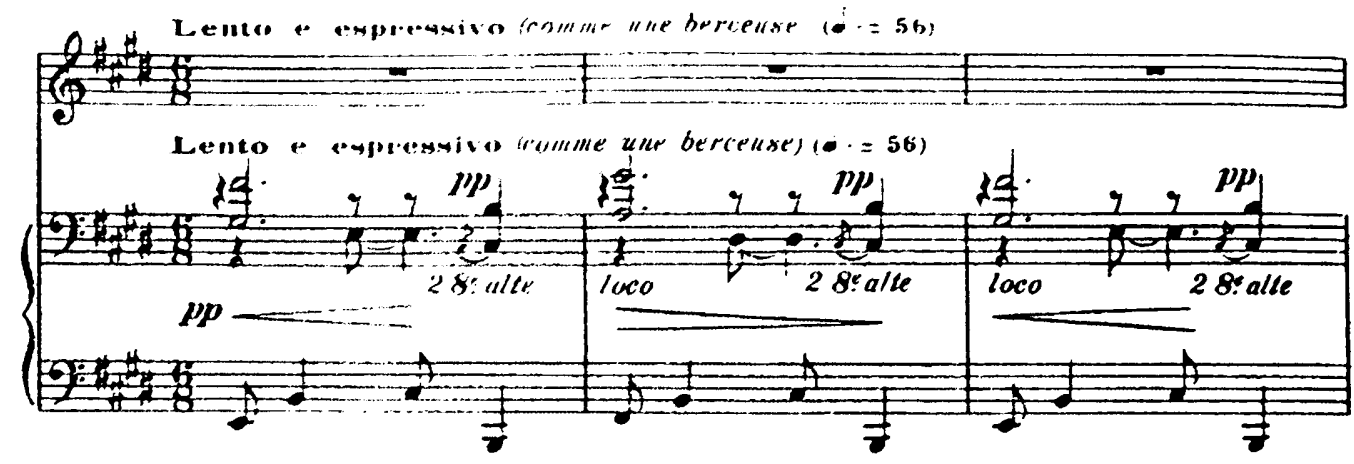

Figure 7 Villancico Vasco: rocking piano figure, mm. 1-3.

The fourth villancico, composed in 1933 to a popular theme, is named after the central part of Spain. This is by far the largest region in that it consists of Castilla y León, Madrid, Castile la Mancha and Extramadura. It is here that Spain's nationalist movement was born. It is here that one hears the influence of the Moors with the "Ay," which is pronounced [a i], accenting and holding out the second vowel, [i]. Also present is the dance rhythm, which celebrates that from humble beginnings paradise has come. 

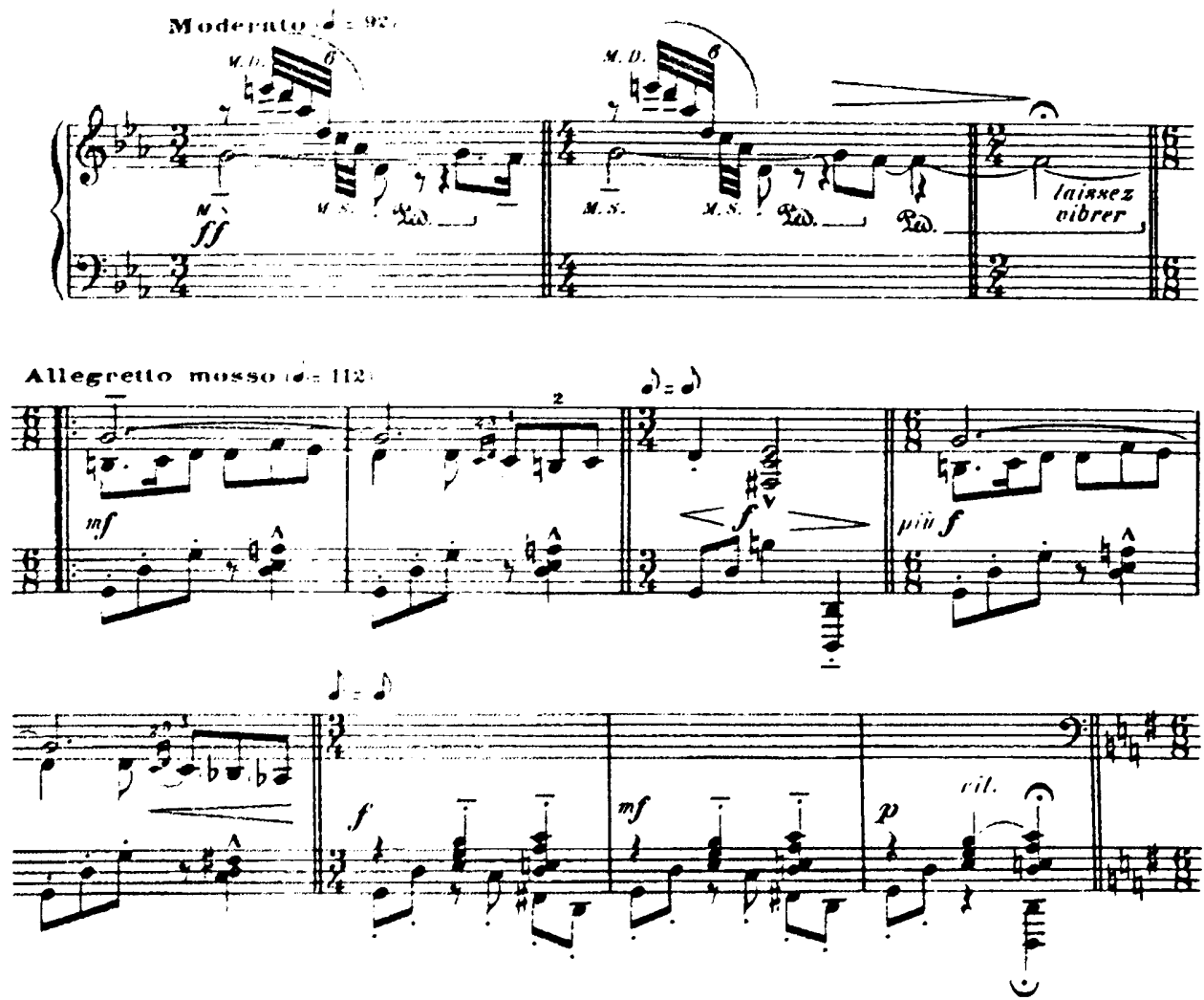

Figure 8 Villancico Castellano: piano introduction, mm. 1-11.

The fifth villancico is based on a popular theme from the region of Córdoba, which is located within Andalucia. This area was founded by the Romans due to its strategic importance as the highest navigable point of the Guadalquivir River. It was a major port city and we can hear the Moorish influence in the use of the appogituras and f\# leading tone. This villancico, composed in 1932 , also contains an emphasis in the poetry of the hard world that we live in where there is no charity. Jesus is in the form of the little boy, in white linen, asking to come in, but the world is closing its door to him. 

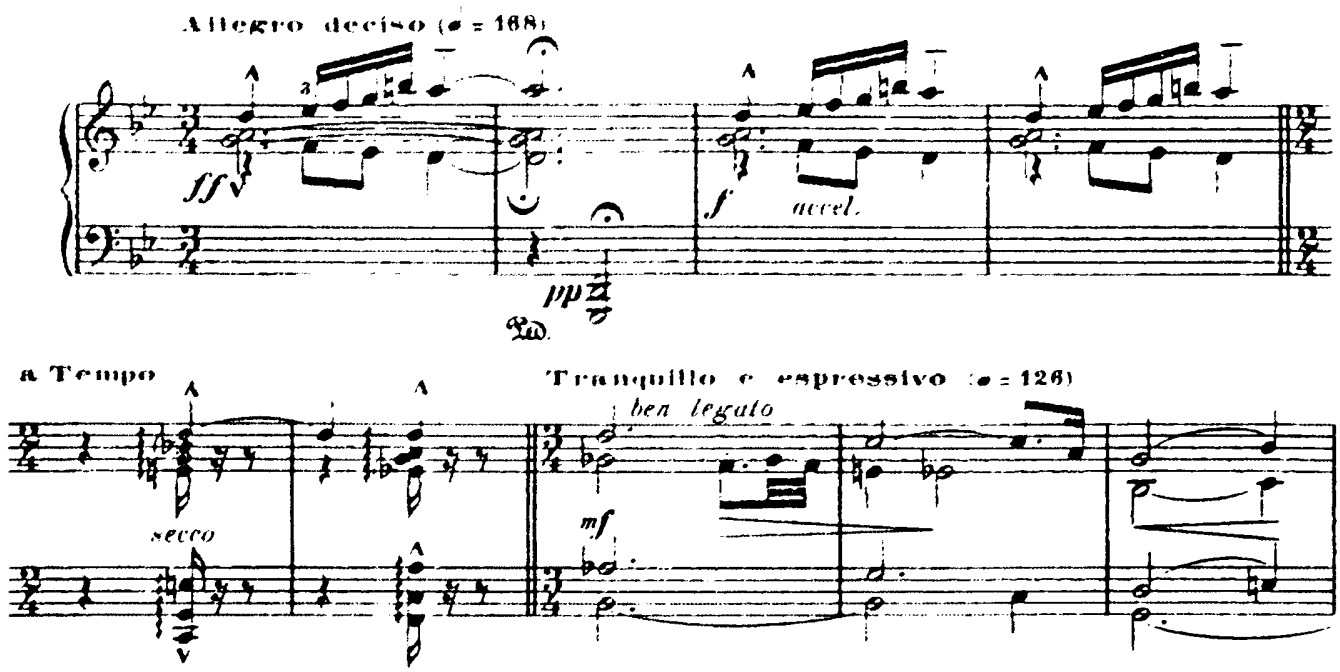

Figure 9 Villancico de Cordoba: piano introduction, mm.1-9.

The sixth villancico composed in 1932 to a popular theme is from the ancient kingdom of Murciano on the southeastern side of Spain between Andalusia and Valencia. The Aguinaldos songs of Christmas such as this one contain simple melodies, triple time and major tonality. This villancico is akin to the Valencian-Catalan group in that they have the typical dance of the region: the fandango. The fandango is $3 / 4$ time with octosyllabic verses, meaning there are eight syllables to each phrase with the emphasis on the seventh syllable. In this song, it is noteworthy that what is translated as "to give birth" is in Spanish "ha de alumbrar" or to enlighten. 


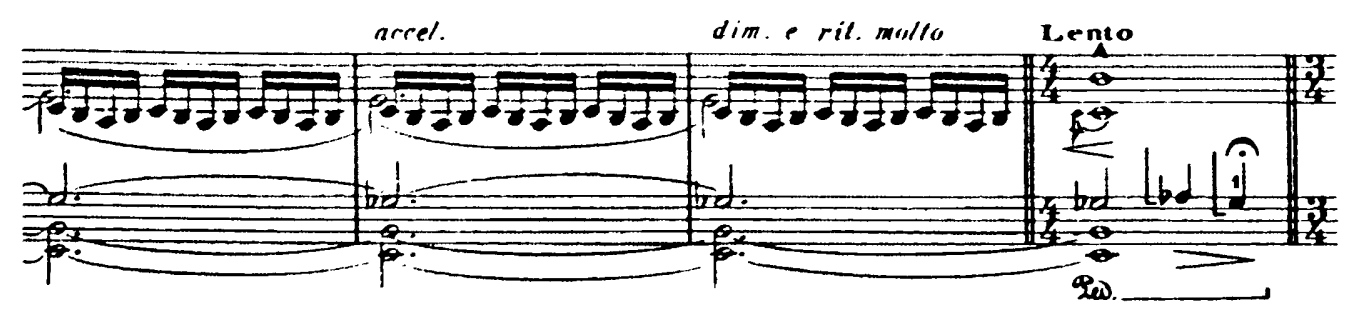

Figure 10 Villiancico Murciano: piano figure, mm. 10-13.

The seventh villancico based on a popular theme, which was composed in 1933, Villancico aragonés, is perhaps the simplest, most typical example of a villancico. It contains four strophes and it is as if one were telling children the story of the birth of the Christ child. It has the references to the stable (el portal or the gateway), the mention of Bethlehem, the mula y el buey (mule and ox). It also speaks to his humble beginnings and who will dress him in velvet, the garment of kings.

The eighth villancico composed to a popular theme in 1933 is referred to as the Second Catalan Carol. The first carol was composed in 1923 and was included in his Canciones populares españolas. This is the only villancico that contains the Greek liturgical phrase, Kyrie Eleison. In catholic services this is what is recited at the beginning of mass and is known as the penitential rite. It is a petition for the Lord's mercy, his forgiveness. However, this is not a sad song, but a celebration of Christ's redemption. It is also in the language of Catalán, the language of his father and it was also the year of his affair with his daughter. Could Nin be asking for mercy?

The ninth villancico is from the southern most region of Spain, Seville in Andalucia. It is the only villancico not referred to as a villancico, but with a title, Jesús de Nazareth. Additionally, Jesús de Nazareth it is the only one with a completely original melody, one 
that is not from a popular folk theme. This villiancico was composed in 1933 and is the only one with a reference to a poet, Rodrigo de Reinosa, an early $16^{\text {th }}$ poet from the city of Reinosa in the Cantabria region. This poet was famous for his irreverent verses about the brothels of Seville. Reinosa did write one religious set called the Songbook of our Lady. There were four main factors in the development of Andalusian folk music 1) adoption of many elements of Byzantine chant by the primitive church in Spain; 2) Muslim invasion and occupation for centuries 3) Immigration by the gypsies, most of which settled in Andalusia 4) the cante Jondo or Jewish synagogue chant. The Cante Jondo is characterized by the use of microtones, sliding the voice from one note to another and melodies that move within a sixth. Also a single note repeated accompanied by appoggiaturas from above. The melodic embellishment is as a result of the lyrical expansiveness caused by the emotive force of the words. Although Andalusia is often thought of as a land of "perpetual gaity," suffering is the chief burden of most of the songs of the region, certainly those of the Arabic-Hebraic-Gypsy variety. Anna Bartos in her article entitled, "The Golden age revisited in $20^{\text {th }}$ century art songs" believes that this song has the precursor in a Sephardic lullaby sung by a mother who is anxiously awaiting her husband's return from the fields, all the while fearing that he has been unfaithful to her (DaSilva 2004, 57). This villancico is dedicated to the Christ Child and has the verso octosilábico or eight syllable lines with stress on the seventh, in a rima asonante rhyme of the penultimate vowels, common to the Golden Age of poetry (DaSilva 2004, 58).

Un niño nace de flores, Todo vestido de amores, Es de las flores la flor, Y el amore de los amores 

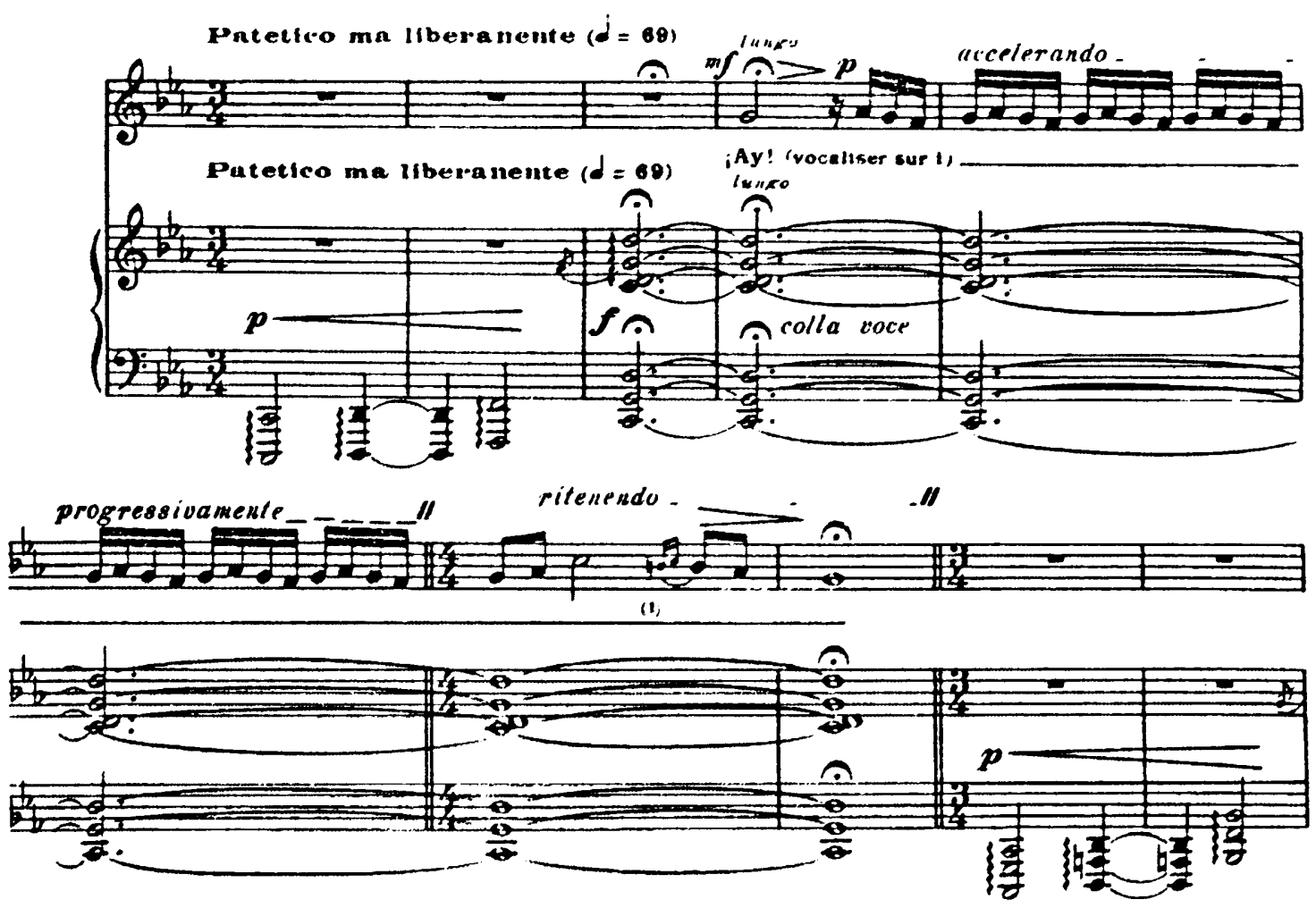

Figure 11 Jesús de Nazareth: “Ay!” Vocal motive: mm. 1-10.

The tenth and final villancico, Villancico Andaluz, was composed in 1932 and it is from a very popular theme, one that has remained to this day a favorite Spanish carol. It is a joyfully rhythmic celebration of the birth of our Savior. The piano introduction contains the celebration of the "bells" in the last three large chords contains the nativity story and the bells played by the angels (campanas de Belén que los angeles tocan) announcing His birth. 


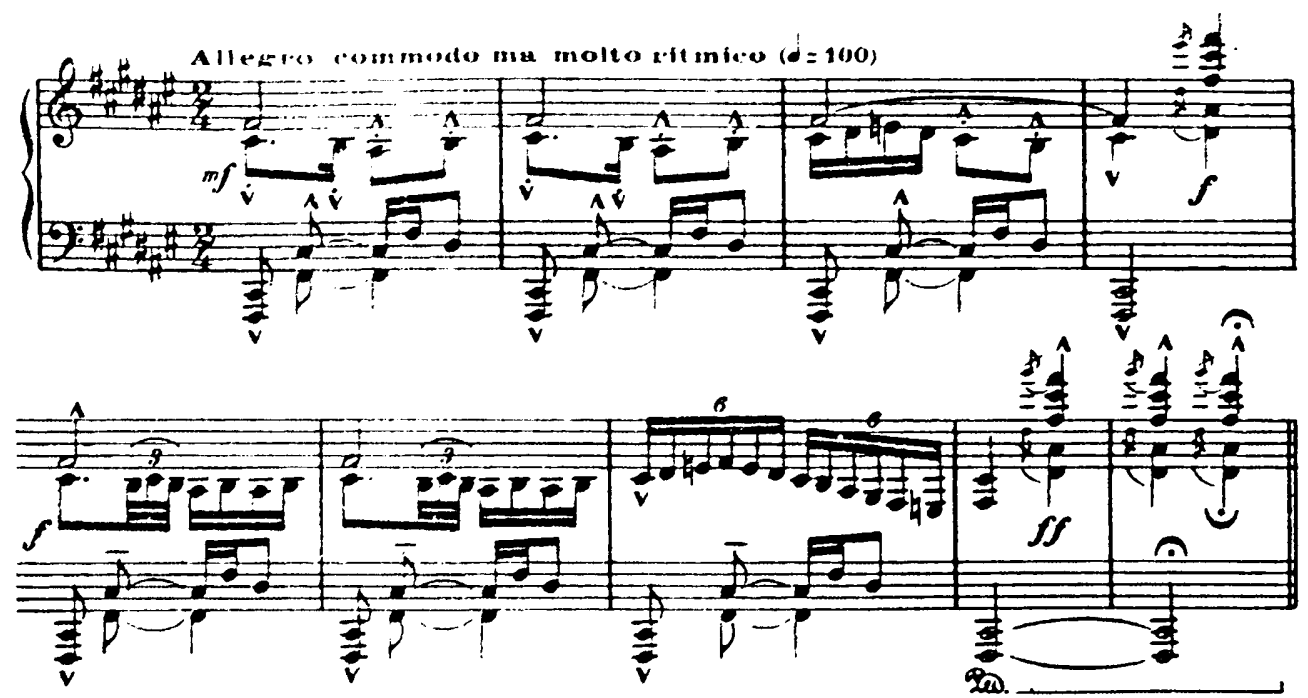

Figure 12 Villancico Andaluz: piano introduction, mm. 1-9. 
IV. Gabriel Fauré: Three Songs

"Fauré (1845-1924) is often categorized as a mere salon composer, and in the best sense of the word he was. The small musical forms, particularly songs, piano pieces and chamber music, music meant to be performed in a relatively small intimate space - make up the bulk of his compositions." (Gartside 1996, 19) Fauré's education during his formative years significantly influenced his compositional tendencies. Fauré was born on May 12,1845 , in the small town of Palmiers to a modest family. He was trained in the strict Niedermeyer School that focused on music composed before 1750. Niedermeyer became a teacher and father to the young Fauré, for Fauré became the "apple of his eye" (Nectoux 1991, 8). Already naturally a modest man, his education at the Niedermeyer School solidified his taste for restraint in composition and abhorrence of the use of dramatic grand gesture. Niedermeyer suddenly died in March of 1861, which devastated the boy. However, shortly after this time of distress, Fauré met Camille Saint-Saëns (1835-1921), who would become more than a teacher, but also a friend and mentor. It was under Saint-Saëns's tutelage that Fauré began to compose. However, Saint-Saëns not only influenced his compositional style, but also helped him in a more practical and financial sense, by introducing him to the wider musical world and members of the elite. It was Saint-Saëns who exposed Fauré to Victor Hugo, Schumann and Wagner. Additionally, it was his introduction to the Paris elite community that would gain him entrée into various musical soirées. There his songs could be performed by amateur singers, most often women. In fact, since it was very much in style for young women to study voice during that time, Fauré often served as accompanist to these amateur singers. 
While his compositions were being performed in the salon, the contemporary artistic community of France was also discussing them. During the first quarter of the twentieth century, the highest compliment to a composer would be that he be hailed as sincere, that he would be able to "maintain a singleness of voice amid such variables as poetic inspiration, genres, forms, and the passage of time" (Caballero 2001, 15). When one hears a song or piano work by Fauré, it is clear that it can be none other than his composition.

Paul Dukas, a noted French composer himself, expresses eloquently in an essay a few years after Fauré's death how linked Fauré's compositions were to his character as a person:

In every beautiful work, it is the man the work expresses that counts first and foremost.

In this, what more luminous example to follow?

Those who had the joy of sharing Fauré's intimacy know how faithfully his art reflected his being - to the extent that his music at times would seem to them the harmonious transfiguration of his own exquisite charm. Others did their utmost to rise above themselves or, if they collaborated with a poet, to surpass that collaborator. Fauré, with a unique grace, without constraint, gathers every external impression back into his inner harmony. Poems, landscapes, sensations that arise from the spur of the moment or the fleeting wave of memories - whatever sources his music springs from, it translates above all his own self according to the varied moods of the most admirable sensibility (Caballero 2001, 24).

In the world of the French chanson, Faure is regarded as one of its greatest masters, having composed over 100 chansons, with the majority being grouped in three collections. His musical settings have several distinct characteristics. Most notable are his handling of harmony and tonality where there are temporary modulations, 
modulations to remote keys and the use of the plagal cadence due to his early training in church music. Melodically, he tends to think more horizontally instead of vertically, with the melody being a linear expression of the harmony. Rhythmically, Fauré favors line over pulse, creating a sense that the music is seamless, much like the French language itself. Fauré was enormously careful in his choices of text. However, "he always tended to choose poetry in which the evocative character of the words was greater than their sonorous quality. It was the general 'feel' of the poem that interested him, not the meaning of particular words" Gartside, 1996, 24). Fauré is not concerned with text painting, but with creating an atmosphere, foreshadowing Debussy and Impressionism.

Dans les ruines d'une abbaye, op.2, no.1was composed in 1865 and is based on the poetry of Victor Hugo (1802-1885). This through-composed composition can be found in the Fauré's first collection of 20 songs. In that same year, 1865, Victor Hugo, $19^{\text {th }}$ Century poet, writer, theoretician and leader of the Romantic movement, published a set of poems entitled, Les chansons des rues et des bois, or The songs of the streets and woods. In Book One: Youth (Livre Premier: Jeunesse), Section VI, The eternal little romance (L'Eternel petit romance), one finds playful number 15, "In the ruins of an abbey." The poems compare the beginning and ending of a man's life. Here the text speaks of love and it is not until the very end that we realize that it is speaking not of two people, but of two birds. Fauré uses a relentless quarter note, eighth note, quarter note, eighth note $6 / 8$ rhythmic pattern in the voice part which matches the rhythm of Hugo's lengthy poem, but is not particularly musically interesting. It is important to sing with a seamless legato line, being mindful of the eighth notes in order to not shorten them. This 
rhythmic pattern coupled with the four-measure phrases in which the vocal line rises and falls seems to symbolize the playfulness and joy of the birds love.

The next two selections, Les Berceaux, op. 23, no. 1 (composed in 1879) and Au bord de l'eau, op. 8, no. 1 (composed in 1875) contain poetry by the first Nobel Prize Winner in Literature, Armand Sully Prudhomme (1839-1907). Prudhomme's poetry seems to embody Fauré's personal esthetic of restraint, sensibility and profound melancholy. In fact, Fauré was attracted to many of the poets like Prudhomme, who were of the Parnassianism movement, who espoused the ideal coined by Théophile Gautier of "art for art's sake." Prudhomme, Gautier and some 90 other poets in the movement strove for purity of form and art over other personal or social concerns. Additionally, both chansons express an affinity for the sea.

Les Berceaux is one of Fauré's most popular songs for the text is "immediately appealing, one with which many individuals can readily identify" (Gartside 1996, 104). Marie Claire Beltrando calls this "one of his finest and most somber songs," a "lullaby of death," a forshadowing of the Requiem (Nectoux 1991, 76). What is most ingenious about this composition in $\mathrm{ABA}$ form, is his use of the accompaniment to establish the rocking motion of ships, which is being compared to the rocking of the cradles. It is written in $12 / 8$ time and the piano starts simply, repeating the same tonality for the first two measure. The left hand starts with a series of triplets, but the last eighth note of the first triplet is tied to the first eighth note of the second triplet. The right hand has a continuous quarter note eighth not rhythm. This combination creates a feeling of rocking in the right hand and pitching in the left (Gartside 1996, 104). 


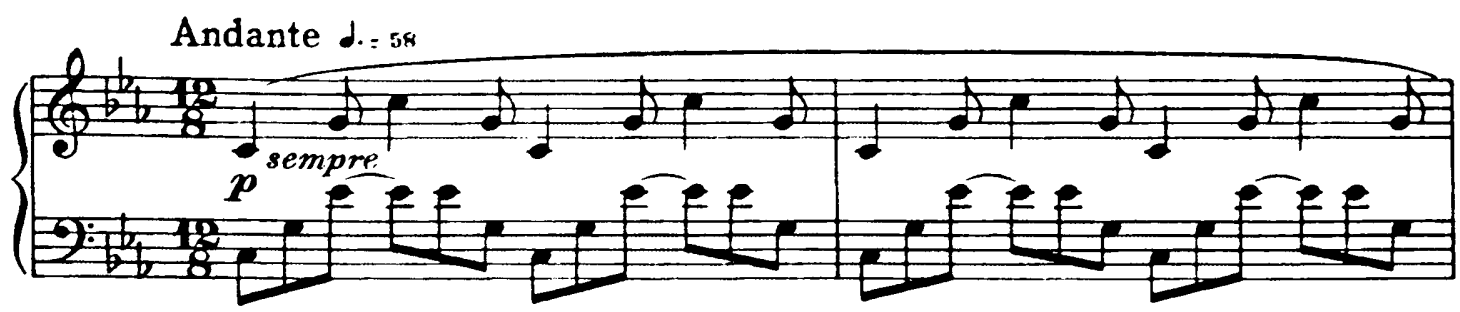

Figure 13 Les Berceaux: piano introduction with rocking rhythm, mm. 1-2.

Once the voice enters in the third measure, it seems as if the vocal line is growing right out of the piano part. The second section begins when the text speaks of the time of farewells and is marked with the vocal line written in even dotted quarter notes. Little by little there is a crescendo as the women begin to cry as the curious men are enticed to distant shores. He moves the main notes of the vocal line chromatically, building to a surprising altered III. Once the climax is reached, the vocal line floats back down an octave, symbolizing the men's yielding to the temptation of the life on the sea that they love. He modulates back to the original key and the A section returns, with alterations. Only the last line of the poem is repeated, Par l'âme des lointains berceaux (by the soul of the distant cradles). This is Fauré's song with the largest range, that of a $13^{\text {th }}$ and ending on a beautiful low note, the tonic, expressing the deep emotions of the Breton women who lost so many of their men to the call of the North Atlantic Sea.

Au bord de l'eau is a dreamy, somewhat melancholy chanson. The chanson begins in what became "one of his trademarks: a series of simple unadorned chords that the vocal line then spins out" (Gartside 1996, 75). Just as the poetry has the pattern of repeating the idea of the last line, the voice seems to continue the idea that the piano starts. Au bord de l'eau was composed during the time when he was in love with Madame Pauline Viardot. The songs during this period have the formula that Nectoux 
calls the "Viardot motif" of a rising sixth or octave followed by a stepwise descent down the scale, which is V, IV, III, II, I, VII, I (Nectoux 1991, 71). In the case of Au bord de l'eau, the descent is in equal eighth notes and requires a seamless legato. The ebb and flow of the melody seem to evoke the ebb and flow of the tide, giving the love a sense of timelessness. However, unlike Les Berceaux, the love is not lost but is depicted with the tonality changing from $\mathrm{c} \#$ minor to $\mathrm{C} \#$ Major, as never passing away (ne point passer). 
V. Sergie Rachmaninov: Three Songs

The greatly renowned Russian born pianist, conductor, and composer Sergei Rachmaniov (1873-1943) composed Oni otvechali, Op. 21, no. 4, Zdes Khorosho, Op 21, no. 7, and the Vocalise, Op. 34, no. 14. Rachmaninov occupies a very important place among Russian composers, being considered by music historians to be the last great representative of Russian late Romanticism (Slonimsky 2001, 2904). Rachmaninov composed some 82 songs from 1890-1916, a time considered to be the end of the Golden Age of Russian culture and the time of the Silver Age of refinement and drama.

When one thinks of Russian music, one thinks of the great symphonies of "the Mighty Handful"- Balakirev, Cui, Borodin, Musorgsky, and Rimsky-Korsakov or Tchaikovsky. When one thinks of Rachmaninov, one thinks of his great works for the piano with its broad rhapsodic sweeps of melodic line, fully expanded sonorities and fine, resonant harmonies. However, Russia has a "pesennaya kultura, a culture of song, where all of life, its joys and sorrows, holy days and work days were reflected upon in song. To sing (pet') expresses a vast range of feeling and emotion" (Challis 1989, 32). Song therefore is at the heart and soul of the Russian people and their music.

Rachmaninov entered the Moscow Conservatory to study and live with Professor Nikolai Zverev in 1885 . It was at the conservatory that he also became acquainted with Tchaikovsky, one of his great mentors. During the summer of 1890 Rachmaninov stayed at Ivanovka, the country estate of the Satin's his distant relatives. Ivanovka, deep in the Russian countryside and some 600 kilometers from Moscow became a place of retreat and respite for the composer. It was here that Rachmaninov would meet and marry his 
wife Natasha as well as compose more than thirty of his songs and over eighty-five percent of his total musical compositions. It was in Ivanovka that he was able to work poetically through loss and sorrow, "mellowed by the peaceful images of nature" (Challis $1989,40)$.

The vocal music of Rachmaninov derives its inspiration from liturgical poetry, Russian folk tradition and the secular poetry of Russia. What is interesting about these three genres is that they are all decidedly spiritual in nature. It would seem that to the Russian psyche, one cannot separate art apart from the spirit. When describing his own process, Rachmaninov states that "I compose slowly...for a long time, I walk surrounded by nature. My eyes encompass the reflection of light on leaves, fresh from the rain; I listen to the quiet whisper of leaves in the forest, or I observe the pale nuances of the sky on the horizon, and in my soul voices arise, all at once. Not a drop here, or a drop there, but all at once - a whole song arises" (Challis 1989, 45). For Rachmaninov, nature and particularly the Russian countryside was his source for vocal inspiration. After 1917, the year of his exile from his motherland, although he continued to perform and teach, he ceased to write songs.

Oni otvechali and Zdes Khorosho are from Rachmaninov's Songs of Opus 21, composed in 1902 at Ivanovka. The themes of these songs center around the idea that suffering and loneliness are inevitable parts of life, but emotional and spiritual understanding can be achieved through suffering. This is a decidedly Russian Orthodox concept with the emphasis of salvation and peace coming from the suffering on the cross of the savior of the world. 
Oni otvechali (They answered) is dedicated to Elena Kreutzer and is based on the poem Autre Guitare, (other Guitar) No. 23 from Les Rayons et les ombres (Rays and Shadows) published in 1838 by Victor Marie Hugo (1802-1885) and translated by Lev Alek Sandovich Mey (1822-1862). The great French Romantic poet Victor Hugo believed that by bringing poetry closer to man, making them walk universal paths above the struggles and parties of life, they would become civilized. In his collection of poems Les Rayons et le ombres Hugo juxtaposes the "rays" of passing through the joys of beauty, love and nature and the "shadows" of sadness, forgotten heroes, dead kings in order to form what we call life. Hugo entitles the poem Autre Guitare to poetically evoke guitar music. Rachmaninov seems to evoke the guitar in the accompaniment with its rolling chords. The poetry is a dialogue between men and women and utilizes the archaic Nominative plural masculine and feminine personal pronouns in order to retain the notion of "women's" answers to "men's" questions (Richter 2000, 39). In order to depict the poetry, Rachmaninov poses each question with urgency and a tempo marked allegro vivace; however, each answer is marked pianissimo, as if the women (and this is a decidedly feminine voice who answers) speak only in a whisper. 


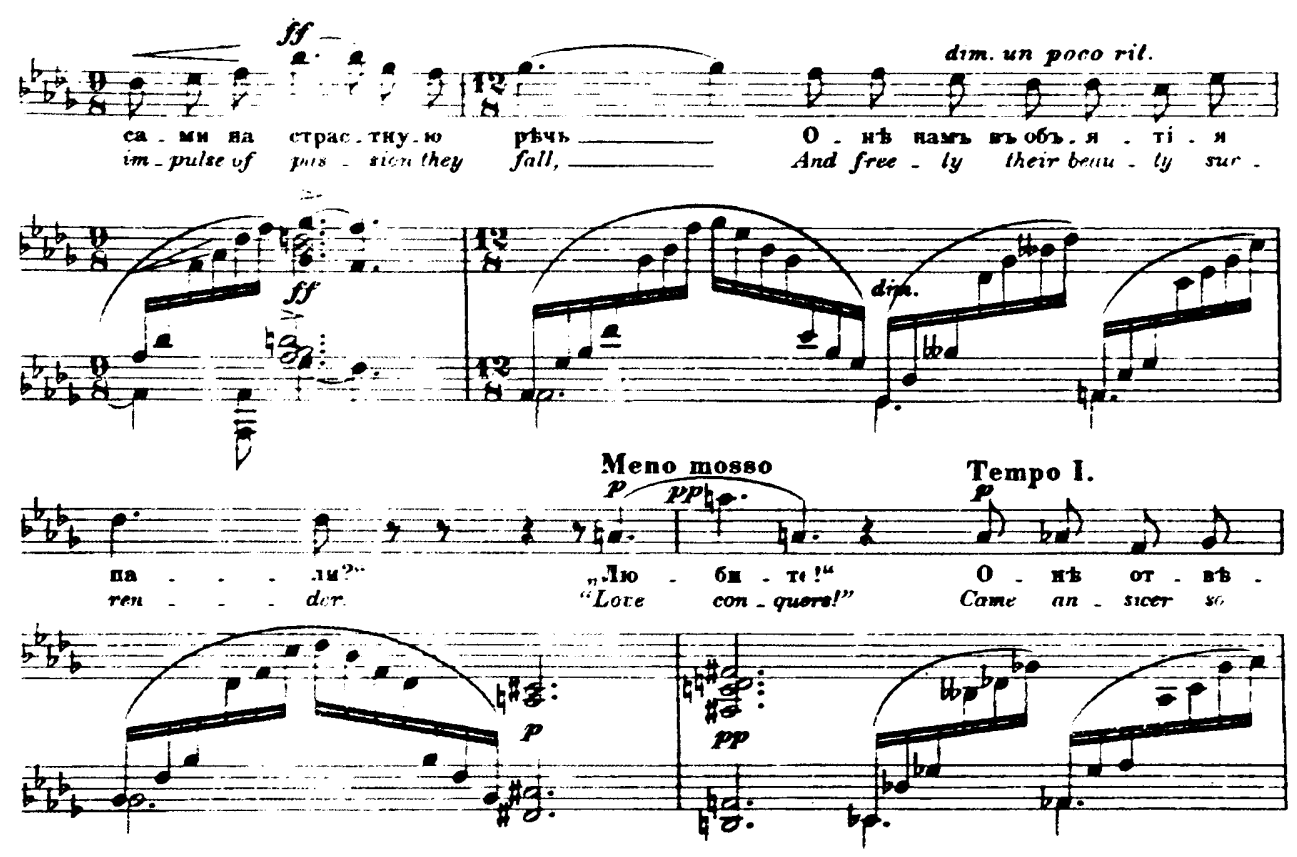

Figure 14 Oni otvechali: vocal part with the last "answer", mm. 18-24.

As each question is posed, the dynamics increase in volume, but the answer is always in a whisper, no matter how high the note the singer must sing, no matter how passionate the question, whether it concern how to succeed in life, happiness or love. All this would indicate that as we struggle with life's questions we must just listen attentively for the simple answer, to keep going, to sleep, to love.

Zdes Khorosho, (Its nice here) Op. 21, No. 7 contains poetry from a lesserknown poet, Glafira Galina, under the pseudonym Countess Einerling (1870-1942). However, do not be deceived by its humble origins, this musical offering is but a moment of outstanding beauty. In Zdes Khorosho, "Rachmaninov uses the melodic development of Russian protyzahnye (slowly sung) folk songs in which images of nature portray the spiritual and emotional state of the singer (Challis 1989, 102). Rachmaninov uses the triplet piano figure to invoke a feeling of $12 / 8$ time while the 
voice must soar quietly in $4 / 4$. The first notes are a and c\#, but it is it major or minor? It is not until the second measure that we realize we are not in A major, but $\mathrm{f} \#$ minor. The dominant is also minor and does not contain an e\# in the chord. The wonder that is expressed in the singer's voice, with its high tessitura sung pianissimo, complicated by the compound rhythmic figure is a wonder that is unsettled, not completely restful. There is a sense of awe as the singer states that there are "no people, only silence, only God and I." When the vocal line reaches its zenith, it is with a pianissimo that speaks louder than any forte ever could. The voice culminates in $\mathrm{f}$ minor, but the piano lingers, prolonging the beautiful moment, finally resting in a peaceful A major chord. As Vasinia-Grossman, so beautifully states, the "melody reveals itself in its unexpected beauty, as if realizing in music all the wealth of feelings, thoughts, reminiscences, which rise in our souls from a glance at familiar scenes of nature" (Challis 1989, 102).

The third selected song, Rachmaninov's Vocalise, Op. 34, No. 14, composed in 1915 published in 1916 and dedicated to the renowned Russian Soprano, Antonina V. Nezhdanova. Throughout his Opus 34, Rachmaninov brings together elements of ancient Russian chants and the classical tradition of the $19^{\text {th }}$ century, in contrast to the increasing modernism of Russian arts during the early years of the $20^{\text {th }}$ century. The Vocalise is the last song of the cycle, the only one composed in 1915, as opposed to 1912 when the rest of the Opus were composed. Here "words give precedence to the world of pure sounds" (Challis 1989, 171). In this song, Rachmaninov's affinity for Russian chant is most clearly evident for the free melody has its basis in a brief initial motif that is sung in variations, much like that of a Baroque Aria. Without the use of 
words, the voice becomes an obbligato instrument with the thematic material alternating between the voice and the piano.

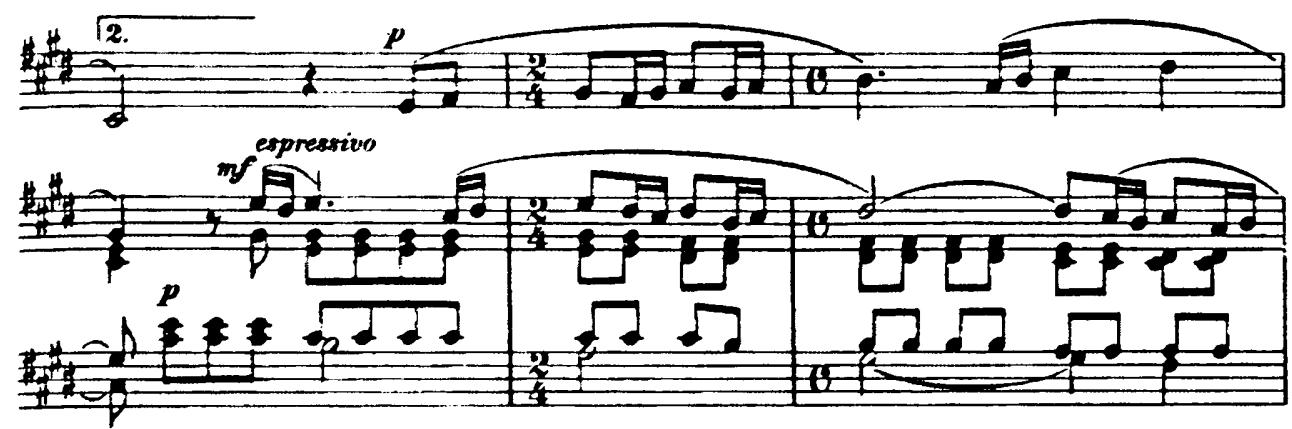

Figure 15 Vocalise: voice and piano counterpoint, mm. 33-35.

For Rachmaninov, the melody was music, "inasmuch as a perfect melody presupposes and calls to life a harmonic activity" (Challis 1989, 170). This hauntingly beautiful and melancholic melody seems to be infinite, penetrating the soul. 
VI. Libby Larsen: Cowboy Songs

Living composer Libby Larsen composed the set of three songs titled Cowboy songs in 1994. Although these three songs share a common theme of the Old West, they can be performed separately. Libby Larsen, born Elizabeth Brown Larsen in Wilmington, Delaware, is one of the most performed living composers, which is particularly noteworthy since she is one of only a handful of living composers that are not attached to a particular institution. Larsen not only is able to "make a living outside of Academia; she is one of America's most successful living composers, a major voice in American music" (Secrest 2007, 21). In her over 100 works that are comprised of choral works, song cycles, symphonic poems and opera, Larsen displays incredible versatility, for she is able to combine traditional and contemporary idiom to any given work. "Larsen approaches music as a total sensory experience flowing from speech. It employs all senses, not just auditory" (Burns 2002, 366).

During the course of her career Larsen has been a major force in promoting American Music. In 1973 she co-founded the Minnesota Composers Forum (now called the American Composers Forum), she has received numerous awards including a National Endowment for the Arts Composer Fellowship and in the same year that the Cowboy Songs was composed, Larsen won a Grammy Award for her Sonnets from the Portuguese. Larsen's music is immediately accessible with its emphasis on natural speech patterns, expressive piano accompaniments and easily relatable texts. Harmonically, Larsen is neither attached to the ideas of functional harmony, nor opposed to it. The driving force is simply the prose. In Larsen's own words, she states that her style is not recognizable in a "consistent use of harmonic language.... but in 
its rhythm." She believes that music "springs from the language of the people"... and she is "intensely interested in how music can be derived from the rhythms and pitches of spoken American English" Secrest 2007, 22). Larsen cites a varied list of influences from Gregorian Chant to Beethoven, to Blues, Techno and Rock and Roll. Gregorian Chant in particular laid a foundation for her concept of rhythm with its lack of bar lines. In fact, in an interview with Linda Moorhouse Larsen illustrates her affinity for what she calls "free flow" by first composing the music and then later creates a "grid of bar lines and meters" that she hopes will "make the music flow naturally"(Salzman, p.56).

The common subject of the American cowboy is what unites the three pieces titled Cowboy Songs. The text for the first song, "Bucking Bronco" is attributed to the female American outlaw, Belle Starr, alias Myra Maybelle Shirly, who was born in Missouri in 1848. Although immortalized in film and folk song, the Carthage Female Academy educated Belle was not a major criminal, but she was a horse thief. Her life was brought to an unfortunate end in 1889 , when she was ambushed and left to die.

In "Bucking Bronco," Belle speaks of her failed love affair with a cowboy. The song begins with the voice a capella in a rather free style, where there are twists and turns in the setting of the word "love," depicting the twists and turns of Belle's love with the cowboy. After the vocalist sings "rider" the second time, the accompaniment is energetic and rollicking, creating the feeling of being at a rodeo. 
The vocal line is very melodic and contains few leaps, which are used as a textpainting device as in the words "wild," "jump," and "high."

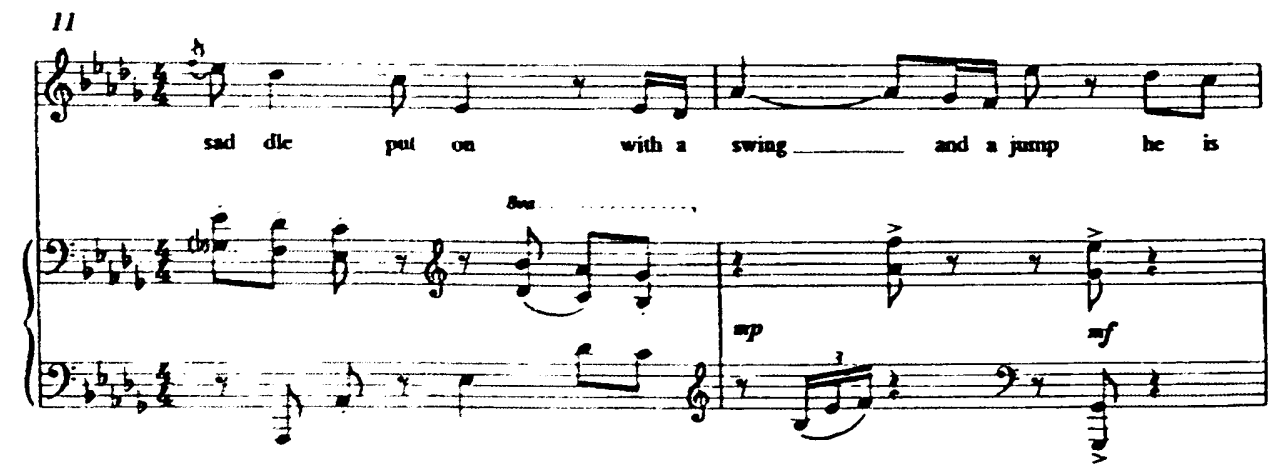

Figure 16 Bucking Bronco: example of text painting, mm. 11-12.

Since the language of the text is straightforward, so is the harmonic language, with standard chordal progressions in D Major. In addition, Larsen utilizes shifting meters of $6 / 4$ to $4 / 4$ and $3 / 4$ to accommodate the text. The structure is ABA, as it is for all three songs. When the A section returns, the voice is again a capella as the singer speaks clearly to the audience her warning about the perils of dating a cowboy. The piano part once again expresses the feel of the cowboy riding his bronco with the repeated rhythmic figure of four eighth notes played staccato followed by two rests. The song also makes use of double entendre with its references to "riding" being the way that he won her heart, which can make for a rather interesting interpretation of the text. 


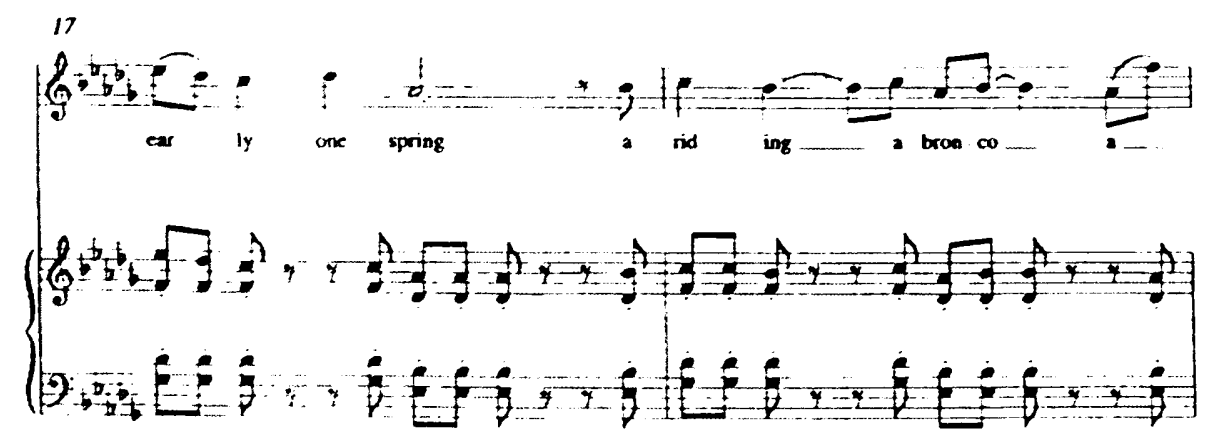

Figure 17 Bucking Bronco: piano rhythmic figure, 17-18.

The second song, "Lift me up to heaven slowly" is based on the poem published in 1978, "Sufi Sam Christian" by the American poet Robert Creeley (1926-2005). Here the cowboy is pensive, contemplating both his hard life and thoughts of heaven. The spacing of the accompaniment is wide, the metronome marking of slow, with the quarter note at 52 beats per second. The repeated accompaniment pattern seems to represent the movement of riding a horse. Again, Larsen utilizes text painting in the writing of "lift me." Also, there is repeated use in the vocal part of leading tones that must be sung slowly and deliberately, for the singer is "not even sure they want to go" to heaven. These slow chromatic movements help to illustrate a certain reluctance to go to the next level, whether it be taken literally as a spiritual heaven or a carnal, more earthly one. The speaker wants to take her time. 


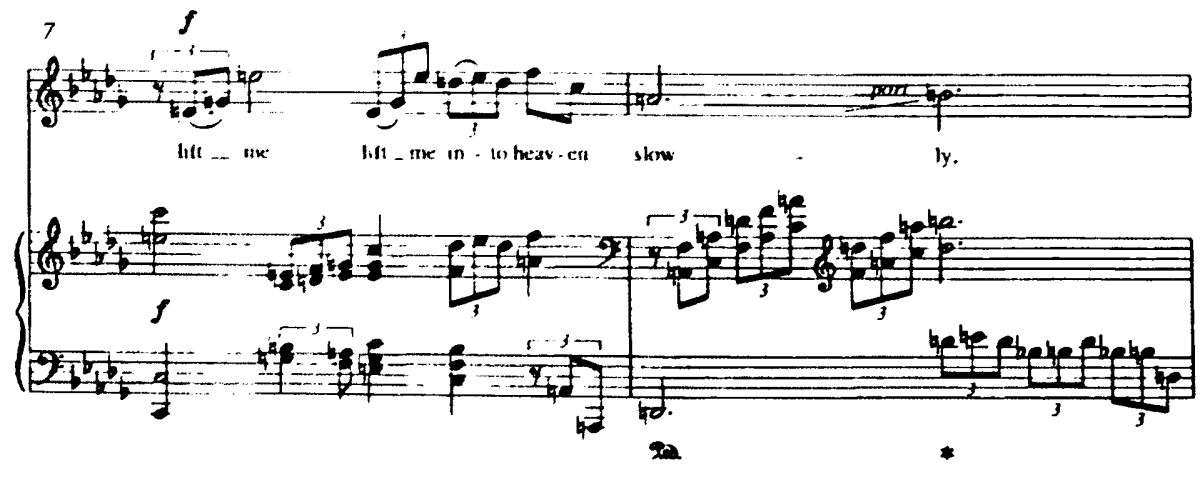

Figure 18 Lift Up To Heaven: vocal text paining, mm. 7-8.

"Billy the Kid," the last song in the grouping is from an anonymous setting of a rather notorious character. The piano accompaniment contains a musical quote from the familiar American folk song, Shortnin' bread. This quotation adds to the ironic character of the piece about an outlaw that became a legend.

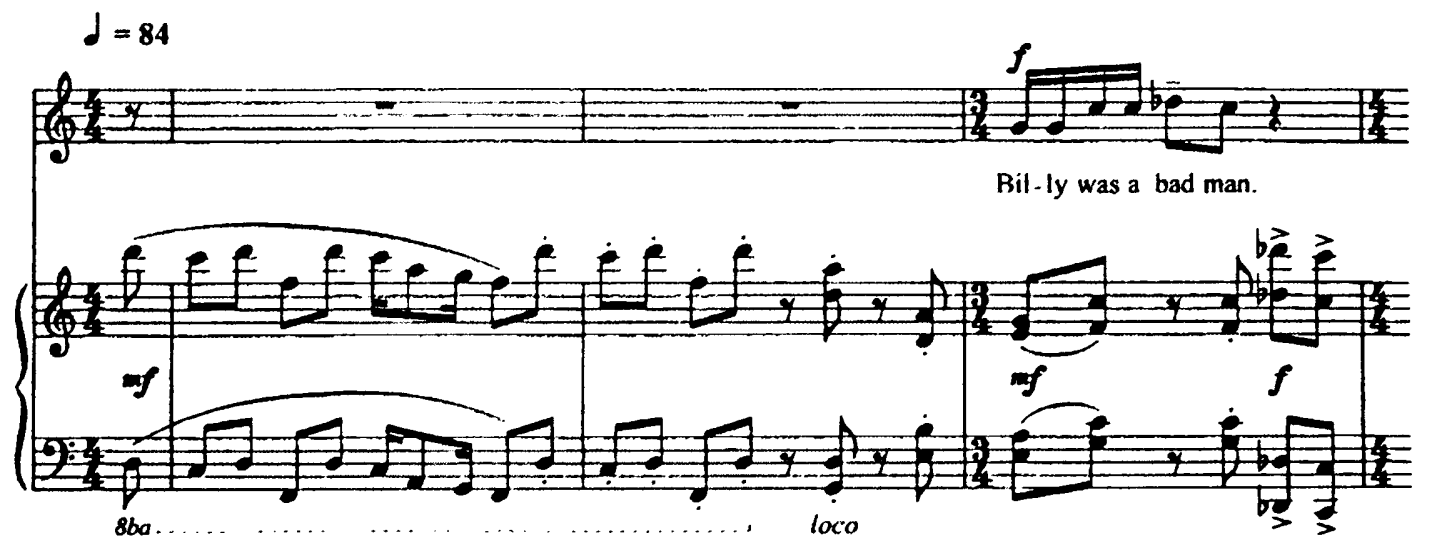

Figure 19 Billy the Kid: Shortnin' Bread quotation in piano accompaniment: mm. $1-3$.

The vocal writing is agitated, containing both repeated notes and angular leaps. The text is filled with slang and colorful expressions like, "sass him," "feel his steel," 
"dead eye," "badder" and "ain't." The angular patterns of the vocal writing particularly illustrate the speakers "rage". In fact, to more fully emphasize the emotional intensity, the singer can choose to sing the ossia which contains a minor seventh interval leap from $\mathrm{e}^{2}$ to $\mathrm{d}^{\mathrm{b} 3}$.

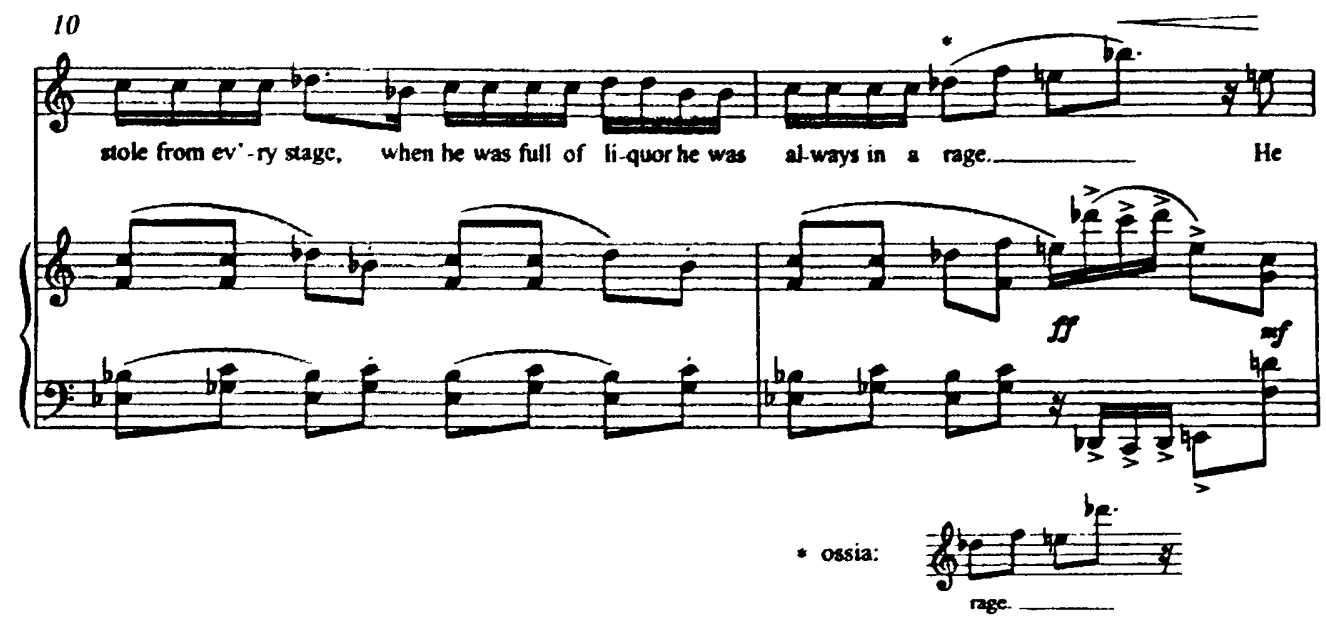

Figure 20 Billy the Kid: text painting of the word rage with ossia, mm. 10-11.

Once the vocal line has reached the sustained climax, the piano accompaniment returns with the ironic folk theme, adding comic impact to the last lines, "now he's dead and we ain't none the sadder." 

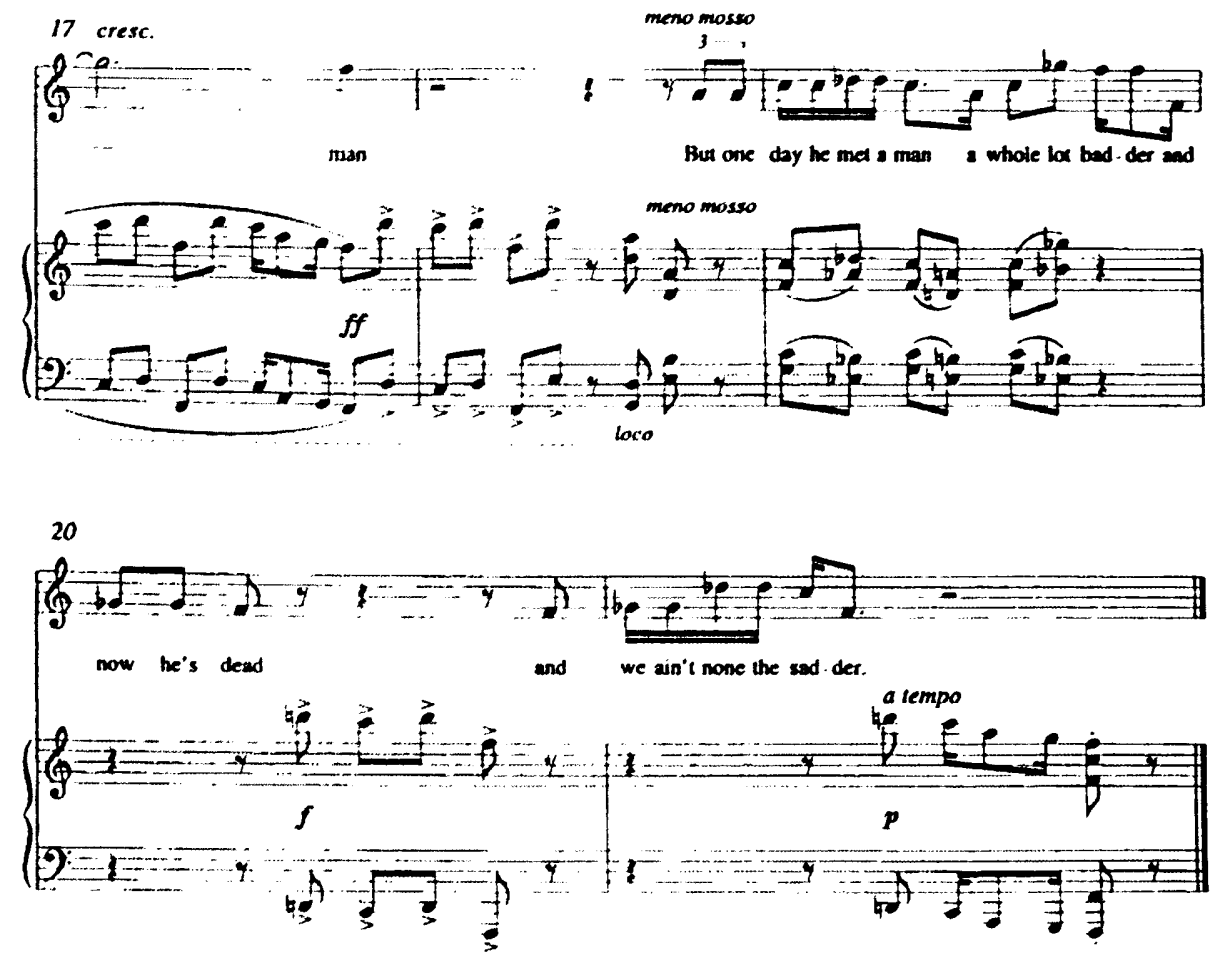

Figure 21 Billy the Kid": Return of Shortnin' Bread quotation, mm. 17-21.

\section{Conclusion}

The composers represented in this master's recital are taken from various styles, time periods, genres and languages. It was the author's intention to select repertoire of highest quality that was uniquely suited to the author's instrument and musical taste. Within the significant output of each composer, the author chose works whose texts resonated with her literary tastes. Lastly, in researching the composers it was discovered with the exception of Mozart, all of the composers wrote extensively on music, its meaning and its cultural significance. The desire on their parts was to serve art itself, a desire that this performer likewise shares. 


\section{LIST OF REFERENCES}

Abraham, Gerald, ed. 1990. New Oxford History of Music, Romanticism (1830-1890). Vol. 9. London: Oxford UP.

Albert, Hermann. 2007. W.A. Moazrt. New Haven: Yale UP.

Bernac, Pierre. 1970. The Interpretaton of French Song. New York: W.W. Norton and Company.

Brewerton, Erik. Rachmaninov's Songs, Music and Letters, 15:1, pp.32-36.

Burns, Kristine H., ed. 2002. Women and Music in America Since 1900. Vol. 2, L-Z. Westport, Connecticut: Greenwood.

Burns, Kristine Helen, ed. 2002 Women and Music in America Since 1900 An Encyclopedia. Phoenix: Oryx Pr.

Caballero, Carlo. 2001. Fauré and French Musical Aesthetics (Music in the Twentieth Century). New York: Cambridge UP.

Challis, Natalia, ed. 1989. Singer's Rachmaninoff. New York: Pelion.

Chase, Gilbert. 1959 The Music of Spain. New York, Dover Publications, Inc. .

Cockburn, Jacqueline. 1992. The Spanish Song Companion. London: Victor Golancz.

Cohen, Aaron I. 1987. International Encyclopedia of Women Composers. 2nd ed. New York: Books and Music

Cross, Eric. 2008. "Telemann Revived." Early Music 36.1, pp. 146-50.

D Silva, Zenia Sacks, ed. 2004. The Hispanic Conncetion: Spanish American Literature in the Arts of the World. New Haven, Praeger Publishers.

Elliott, Martha. 2006. Singing in Style a Guide to Vocal Performance Practices. New Haven and London: Yale University Press.

Gartside, Robert. 1996. Interpreting the Songs of Gabriel Fauré. Geneseo, N.Y: Leyerle Publications.

Johnson, Graham and Richard Stokes. 2000. A French Song Companion, Oxford: Oxford University Press. 
Kimball, Carol. 2005. Song, A Guide to Art Song Style and Literature. Milwaukee, WI: Hal Leonard Corporation.

Johnson, Graham and Richard Stokes. 2000. A French Song Companion. New York: Oxford University Press Inc.

Laird, Paul R. 1997. Towards a History of the Spanish Villancico. Warren, Michigan: Harmonie Park.

Landon, H.C. Robbins. 1990. The Mozart Compendium. New York: Schirmer Books.

Liukkonen, Petri, "René Sully-Prudhomme (1839-1907),"

Kirjasto,http://www.kirjasto.sci.fi/prudhomm.htm (January 8, 2005).

Locke, Ralph. "Laresen: The Cowboy Songs; Sonnets from the Portuguese; Try Me Good King." American Record Guide: Mar/Apr 68.2 (2005): 119-20.

Marco, Tomás, translated by Cola Franzen. 1993. Spanish Music in the Twentieth Century. Cambridge, Massachusetts: Harvard University Press.

Mather, Betty Bang. 1987. Dance Rhythms of the French Baroque a Handbook for Performance. Bloomington: Indiana UP.

McGee, Tomothy J., A. G. Rigg, and David N. Klausner, eds. 1996. Singing Early Music the Pronunciation of European languages in the Late Middle Ages and Renaissance. Bloomington: Indiana University Press.

Nectoux, Jean Michel. 1991. Gabriel Fauré, a Musical life. Cambridge [England]: Cambridge UP.

Neumann, Frederick. 1978. Ornamentation in Baroque and Post-Baroque Music: With Special Emphasis on J.S. Bach, Princeton, NJ: Princeton University Press.

Nin, Anaïs, and Anaïs Nin. 1983. The Early Diary of Anaïs Nin 1923-27 (Early Diary of Anaïs Nin). New York: Harcourt.

Pauly, Reinhard G. 1973. Music in the Classic Period. 2nd ed. Englewood Cliffs, N.J: Prentice-Hall.

Philippians. New American Bible. 1991. New York: American Bible Society.

Psalms. New American Bible. 1991. New York: American Bible Society.

"René François Armand Prudhomme,"

OldPoetry.com, http://oldpoetry.com/authors/Rene\%20Francois\%20Armand\%20Prudhom me (January 8, 2005). 
Richter, Laurence R. 2000. Rachmaninov's Complete Song Texts Russian Texts of the Complete Songs of Sergei Vasilyevich Rachmaninov. Geneseo, N.Y: Leyerle.

Rifkin, Joshua, Colin Timms, George J. Buelow, Kerala J. Snyder, Jack Westrup, and Martin Ruhnke. 1985. The New Grove North European Baroque Masters Schutz, Froberger, Buxtehude, Purcell, Telemann (The Composer Biography Series). Boston: W. W. Norton \& Company.

Sadie, Stanley, ed. 1980. New Grove Dictionary of Music and Musicians, 2nd ed., Vol. 8. London: Macmillan, Grove's Dictionaries of Music.

Sadie, Stanley. 2006. Mozart, the Early Years 1756-1781. New York: W.W. Norton and Company.

Salzman, Timothy Ed. 2003. A Composer's Insight: Thoughts, Analysis and Commentary on Contemporary Masterpieces for Wind Band, Vol. 2, Galesville, MD: Meredith Music Publications.

Sanchez, Marta. 1988. XVII Century Spanish Music Villancicos of Juan Francés de Iribarren. Pittsburgh, PA: Latin American Literary Review Press.

Secrest, Glenda D. 2007. "Songs from Letters and Cowboy Songs by Libby Larsen: Two Different Approaches to Western Mythology and Western Mythological Figures." Journal of Singing, September/October 64.1: 21-30.

Slonimsky, Nicolas, ed. 2001. Baker's Biographical Dictionary of Musicians, Vol. 5 Pisc-Stra. New York: Schirmer Books.

Slonimsky, Nicolas, ed. 2001. Baker's Biographical Dictionary of Musicians, Vol. 6 Stre-Zyli. New York: Schirmer Books.

St. Amour, Mary Paulina. 1969. A study of the Villancico. New York: AMS.

Stevens, Denis, ed. 1970. History of Song. Boston: W. W. Norton \& Company.

Walters, Richard. 1994. The Oratorio Anthology - Soprano The Vocal Library. New York: Hal Leonard Corporation.

Whybrow, Julia. 2009. Celle February. Web.

Wirsén, C. D. af, 2005. "The Nobel Prize in Literature 1901," Nobel Prize Website, http://nobelprize.org/literature/laureates/1901/press.html (January 8, 2005). 


\section{APPENDIX}

\section{SONG TEXTS AND TRANSLATIONS}

I. Georg Philipp Teleman: Lauter Wonne, lauter Freude (translated by Julia Whybrow)

Arie:

Lauter Wonne, lauter Freude, spielt in meiner regen Brust

Doch dem flammenreichen Herzen ist bist jetzt kein sündlichs Scherzen einer eitlen Gluht bewusst:

Gott allein ist seine Lust.

Rezitativ:

Dort labet sich ein Kind der Eitelkeit an aller Wollust dieser Zeit ein andrer ist auf Geld und Gut entflammt und seine Freude wächst zugleigh mit seinen Schätzen; der dritte wünschet kein Ergetzen, das nicht danebst aus hoher Ehre stammt; der vierte, wenn er sich an Feinden rächen kann, sieht dies für sein Vergnügen an; noch andern muß aus andern Dingen der Vorwurf ihrer Lust entspringen. Allein, wie schlecht ist diese Freude, wovon der Grund so leicht, ja oft so plötzlich weicht!

Wie schädlich ist die Weide, Die zwar, den Augen nach, beliebte Bluhmen trägt, und dennoch lauter Gift in allen Blättern hegt!

Ach, welcher sich in Christo nicht erfreut,

Dem bringt sein Freuen lauter Leid.

In Gott allein wird solche Lust gefunden, Die mit Bestand und Seligkeit verbunden.
Aria:

Sheer delight, sheer joy plays in my stirring chest Yet the richly enflamed heart is now unaware of sinful jokes a vain ardour is known God alone is his delight.

Recitative:

There feasts a child of vanity on all kinds of lust of this time another is on money and possessions kindled and his joy is growing simultaneously with his treasures; the third wishes no delight, would derive from high honor; the fourth, when he can on enemies take revenge, sees this for his pleasure; still others have made other things the reproach of their desire arise. Alone, how bad is this joy, on whose grounds so easily yes often so suddenly gives way! How harmful is the willow, That to the eye popular flowers bear, and has in all the leaves poison nurtured!

Ah, those who are in Christ not joyful

To them brings their joy in suffering. In God alone such pleasure is found That with continuity and bliss united. 
Arie:

Ein stetes Zagen, ein ewigs Nagen, ein Trauren, das kein Ziel erhält, beschließet den Jubel der lachenden Welt. Doch wer sich Gott zur Freude setzet, hat beides, was ihn hin ergetzet, und was ihm ewig wohl gefällt.
Aria:

A constant trembling

an eternal gnawing

a morn that receives no goal will conclude the jubilation of the laughing world. Yet to whom God their joy sets has both, making him delighted And for him forever full of pleasure.

II. Wolfgang Amadeus Mozart: Laudate Dominum from Vesperae solennes de confessore

Laudate Dominum omnes gentes

Laudate eum, omnes populi

Quoniam confirmata est

Super nos misericordia ejus,

Et veritas Domini manet in aeternum.Amen
Praise the Lord, all nations;

Praise Him, all people.

For He has bestowed

His mercy upon us,

And the truth of the Lord endures forever. Amen.

III. Joaquin Nin y Castellanos: Diez Villancicos de Noël (translated by Piluca Codina)

\section{Villancico Asturiano}

No hay andar como andar a la una

$Y$ vereis el Niño en la cuna

Que nació en la noche oscura.

de Belén en un portal

Que no hay tal andar

No hay tal andar como buscar a Cristo

No hay tal andar como a Cristo buscar

Que no hay tal andar.

No hay tal andar como andar a las dos Y vereis al Hijo de Dios,

Que por nos salvar a nos sangre quiso derramar

Que no hay tal andar

No hay tal andar como buscar a Cristo No hay tal andar como a Cristo buscar Que no hay tal andar.

\section{Asturian Carol}

Nothing can compare with a walk at one When you see the Child in the cradle, Born in the dark night at Belen in a stable. Nothing can compare.

Nothing can compare with seeking

Christ,

With seeking Christ nothing can compare, Nothing can compare.

Nothing can compare with a walk at two, When you see the Son of God, Who to save us willingly shed his blood. Nothing can compare.

Nothing can compare with seeking Christ, With seeking Christ nothing can compare, nothing can compare. 
Villancico Gallego

Os angeliños d'a Gloria

Cantan cousas d'agradar

Os paxariños d'aterra

Cousas de moito pensar

Falade benbaixo Petade pouquiño

Praque non desperate $\mathrm{O}$ noso Ruliño

Vamas cantando e bailando

$\mathrm{Na}$ millor festa que hay

O nacemento d'o Neño

Qu'es tá n'os brazos d'a Naï

Falade benbaixo Petade pouquiño

Praque non desperate $\mathrm{O}$ noso Ruliño

Villancico Vasco

Ator, ator mutil etxera

Gastaña zimelak jatera

Gabon gaba ospatuteko

Aitaren ta amaren onduan;

Ikusico dok aita bareka

Amabe guztiz kontentuz

Villancico Castellano

San José era carpintero, carpintero ¡Ay!

Y la Virgen lavandera, la vandera ¡Ay!

El Niño bajó del cielo

En una noche lunera

El Niño vino del aire

Camino del paraiso

\section{Villancico de Córdoba}

Madre en la puerta hay un niño

Más bello que flor de lirio

Cubierto de blanco lino

Madre el Niño tiene frío

Que venga a la lumbre y se calentará

¡Ay! Que en esta tierra ya no hay caridad ya no hay caridad

¡Ay! Ya no hay caridad
Galician Carol

The little Angels in the Glory

Are singing agreeable things

The little birds on the Earth

Things to think a lot about

Speak very low Make very little noise

For not to wake our little Child

We are singing and dancing

During the greatest feast to exist

The birth of the Child

Who is in her mother's arms

Speak very low make very little noise

For do not wake our little Child

Euskera Carol

Come, come home boy

To eat dry chestnuts

To celebrate Christmas Eve

Together with dad and mom

You'll see dad laughing

And mom very happy

Castilian Carol

Saint Joseph was a carpenter. Ah!

And the Virgin a washerwoman. Ah!

The child came down from heaven

on a moonlit night

The Child came from the air

On the road to Paradise.

\section{Cordovan Carol}

Mother at the door there is a boy

Prettier than the Iris

Dressed in white linen

Mother the child is cold

Let him come to the fire to warm up $\mathrm{Ah}$ ! In this world there is no charity, there is no charity Ah! There is no charity 
Villancico Murciano

Esta noche es Noche Buena

Buena noche de cantar

Que está la Virgen encinta

Y a las doce ha de a lumbrar

Gloria a la Virgen Santísima

Que esta noche ha de a lumbrar ;Ay!

Gloria al Padre Gloria al Hijo

Gloria a la Virgen María ¡Ay!

Villancico Aragonés

Atención a mis complicas

Porque voy con gran contento

A cantar las alabanzas

Del Sacgrado nacimiento

A caballo en un jumento

La Virgen a Belén marcha

Y San José va delante

Pisando nieve y escarcha

En un portalito oscuro

Llenito de telarañas

Entre la mula y el buey

Nació el redentor de almas.

Esta noche nació el Niño

Entre la paja y el heno

¿Quién pudiera, niño hermoso

Vestirte de terciopelo!

Segundo Villancico Catalán

Esta nit es nit de vetlla

Esta nit es nit de vetlla

Ha nascut d'una donzella

La miren i fa sol

Ha nascut d'una donzella

La Kyrie eleison

La Kyrie eleison

Ha nascut d'una donzella

Ha nascut d'una donzella
Murcian Carol

This night is Christmas eve

Good night for singing

The Virgin is expecting

And at midnight will give birth

Glory to the holy Virgin

Who will give birth tonight

Glory to the father, glory to the Son

Glory to the holy Virgin.

Aragonese Carol

Listen to my verses

Because with great happiness

I am going to sing the praises

Of the holy birth,

Riding on a donkey

The Virgin is going to Bethlehem

And Saint Joseph goes in front of her

Stepping on the snow and frost,

In a little dark stable

Plenty of cobwebs

Between ox and ass

The soul's redeemer was born,

That night the Child was born

Among the straw and the hay

Who could pretty Child

Dress you in velvet.

Second Catalan Carol

This night is the night of waking

This night is the night of waking

From a little maid has been born

They see her and the sun shines

From the little maid has been born

The Kyrie eleison. (Mercy of God)

The Kyrie eleison

From a little maid has been born

From a little maid has been born 
Un Infant como una estrella

La miren i fa sol

Un Infant como una estrella

La Kyrie elison

La Kyrie elison

Jesús de Nazareth

¡Ay! ¡Ay! Un niño nace de flores ¡Ay! Todo vestido de amores, de amores,

Es de las flores la flor

Y el amor del los amores.

Es Señor de los señores

Y la flor de los amores. ¡Ay!

Villancico Andaluz

Campana sobre campana

Y sobre campana una,

Asómate a esa ventana

Versa un Niño en la cuna.

Belén campanas de Belén

Que los ángeles tocan -

¿qué nuevas me traés?

Rocogido tu rebaño -

¿A dónde vas pastorcito?

Voy a llevar al Portal

Requesón manteca y vino.

Campana sobre campana

Y sobre campana dos;

Asómate a esa ventana

Porque está naciendo Dios.

Belén campanas de Belén

Que los ángeles tocan -

¿qué nuevas me traés?

Caminando, a medianoche -

¿a dónde vas mi buen pastor?

Le llevo al Niño, que nace

Como a Dios, mi corazón.
A child like a star

They see her and the sun shines

A child like a star

The Kyrie eleison

The Kyrie eleison

Jesus of Nazareth

$\mathrm{Ah}$ ! Ah! A child is born of flowers.

Ah! All clothed in love, in

love,

$\mathrm{He}$ is the flower of flowers

And the love of loves.

He is the Lord of Lords

And the flower of love. Ah!

Andalusian carol

Bell upon bell

And then one more bell, Look out the window

And you shall see a Child in the cradle.

Bethlehem, bells of Bethlehem

Which the angels ring -

What tidings do you bring me?

Once your flock is gathered,

Where dost thou go, little shepherd?

I am bringing to the stable

Butter, curds and wine.

Bell upon bell

And then two more bells,

Look out of the window,

For Christ is being born.

Bethlehem, bells of Bethlehem

Which the angels ring -

What tidings do you bring me?

Walking at midnight,

Where dost thou go, my good shepherd?

I am bringing to the Child, who is being born as God, my heart. 
IV. Gabriel Fauré: Three Songs (Translated by Peter Low)

Dans les ruines d'une abbaye

Seuls, tous deux, ravis, chantants,

Comme on s'aime;

Comme on cueille le printemps

Que Dieu sème.

Quels rires étincelants

Dans ces ombres, jadis pleines de fronts blancs,

De coeurs sombres.

On est tout frais mariés,

On s'envoie

Les charmants cris variés

De la joie!

Frais écho mèlés Au vent qui frissonne.

Gaîté que le noir couvent Assaisonne!

Seuls, tous deux, ravis, chantants,

Comme on s'aime;

Comme on cueille le printemps

Que Dieu sème.

Quels rires étincelants

Dans ces ombres, jadis pleines de fronts blancs,

De coeurs sombres.

On effeuille des jasmins

Sur la pierre.

Où l'abbesse joint les mains, En prière.

Les tombeaux, de croix marqués,

Font partie

De ces jeux, un peu piqués

Par l'ortie.

On se cherche, on se poursuit,
In the ruins of the abbey

Alone together, enraptured, singing, how they love each other!

How they harvest the springtime that God sows!

What laughter sparkling Amongst these shadows Once full of pale foreheads of somber hearts.

They are both newly wed, they exchange the charming, varied cries that spring from joy -

Fresh echoes mingle with the quivering breeze, a gaiety to which the dark abbey adds zest.

Alone together, enraptured, singing, how they love each other! How they harvest the springtime that God sows!

What laughter sparkling Amongst these shadows Once full of pale foreheads of somber hearts.

They pluck petals of jasmine on the marble sculpture where the abbess joins her hands in prayer.

The tombs, marked by crosses, are a part of these games, and so are one or two stings from nettles.

They lay at hide-and-seek; 
On sent croître

Ton aube, amour, dans la nuit

Du vieux clô̂tre.

On s'en va se becquetant,

On s'adôre,

On s'embrasse à chaque instant,

Puis encore,

Sous les piliers, les arceaux,

Et les marbres,

C'est l'histoire des oiseaux

Dans les arbres.

Les berceaux

Le long du Quai, les grands vaisseaux, Que la houle incline en silence, Ne prennent pas garde aux berceaux, Que la main des femmes balance.

Mais viendra le jour des adieux, Car il faut que les femmes pleurent, Et que les hommes curieux

Tentent les horizons qui leurrent!

Et ce jour-là les grands vaisseaux, Fuyant le port qui diminue,

Sentent leur masse retenue

Par l'âme des lointains berceaux.

Au bord de l'eau

S'asseoir tous deux au bord du flot qui passe,

Le voir passer,

Tous deux s'il glisse un nuage en

l'espace,

Le voir glisser,

À l'horizon s'il fume un toit de chaume Le voir fumer,

Aux alentours si quelque fleur embaume S'en embaumer
They feel the coming dawn, Love, growing in the night of the old cloister.

They go on each other kissing They adore one another; They embrace at every moment Then again;

under the pillars, the arches and the statues, it's the story of the birds in the trees.

Cradles

Along the quay, the great ships, that ride the swell in silence, take no notice of the cradles. that the hands of the women rock.

But will come the day of farewells, when the women must weep, and curious men are tempted towards the horizons that lure them!

And that day the great ships, sailing away from the diminishing port, feel their bulk held back

by the spirits of the distant cradles.

At the edge of the water

To sit together beside the passing stream and watch it pass;

together if a cloud glides in the sky, to watch it glide;

On the horizon, if smokes a thatched roof

to watch it smoke, If nearby a flower smells sweet

To savior its sweetness 
Entendre au pied du saule où l'eau murmure, l'eau murmurer,

$\mathrm{Ne}$ pas sentir tant que ce rêve dure

Le temps durer.

Mais n'apportant de passion profonde Qu'à s'adorer,

Sans nul souci des querelles du monde

Les ignorer;

Et seuls tous deux devant tout ce qui lasse

Sans se lasser,

Sentir l'amour devant tout ce qui passe Ne point passer!
To hear at the foot of the willow where the water murmurs, the water murmurs;

to not feel so long as the dream endures, its duration;

but, having no profound passion except to adore one another, without concern for the world's quarrels, to ignore them;

and alone together, in the face of all wearying things, unwearyingly, to feel love (unlike all things that pass away) absolutely never pass way!

V. Sergie Rachmaninov: Three Songs (Translated by Faith Cormier)

Oni otvechali

Sprosili oni: „Kak v letuchikh chelnakh Nam beloju chajkoj skol'zit' na volnakh, Chtob nas storozha nedognali?" „Grebite!” oni otvechali.

Sprosili oni: „Kak zabyt', navsegda, Chto v mire judol'nom jest' bednost', beda,

Chto jest' v njom groza i pechali?" „Zasnite!" oni otvechali.

Sprosili oni: „,Kak krasavic privlech' Bez chary: chtob sami na strastnuju rech'

Oni nam v ob"jatija pali?" „Ljubite!“ oni otvechali.
She Answered

"How then," asked he "By boat and tide Alguazils flee?"

"Row," she replied.

"How then," asked he, "To set aside Strife, misery?"

"Sleep," she replied.

"How then," asked he, "Love's filter denied, Win fair beauty?"

"Love," she replied. 
Zdes' khorosho

Zdes' khorosho...

Vzgljani, vdali

Ognjom gorit reka;

Cvetnym kovrom luga legli,

Belejut oblaka.

Zdes' net ljudej...

Zdes' tishina...

Zdes' tol'ko Bog da ja.

Cvety, da staraja sosna,

Da ty, mechta moja!

VI. Libby Larsen: Cowboy Songs

My Love is a Rider

My love is a rider, my love is a rider

My true love is a rider

Wild broncos he breaks,

Though he promised to quit for my sake

It's one foot in the stirrup

And the saddle put on

With a swing and a jump he is mounted and gone

The first time I met him

It was early one spring

A riding a bronco

A high headed thing.

The next time I saw him 'twas late in the fall

A swinging the girls at Tomlinson's ball.

He gave me some presents

Among them a ring

The return that I gave him

Was a far better thing:

A young maiden's heart.

I'd have you all know,

That he won it by riding his bucking bronco.

Now all young maidens,

Where're you reside,

Beware of the cowboy
How peaceful

How peaceful it is here

Look! far away

the river blazes like fire

The meadows are carpets of color

The clouds are radiant white

There's no one here

Silence reigns

I am alone with the Lord, the flowers, the old pine tree

And you, my dream of delight! 
Who swings rawhide,

He'll court you and pet you

And leave you to go

In the spring up the trail

On his bucking bronco.

Lift Me Into Heaven Slowly

Lift me into heaven slowly,

Cause my back's sore

And my mind's thoughtful

Lift me, lift me into heaven slowly,

Lift me, lift me into heaven slowly,

'cause my back's sore

and my mind's thoughtful

and I'm not even sure I want to go.

I'm not even sure I want to go.

Lift me into heaven slowly, slowly.

Billy the Kid

Billy was a bad man,

Carried a big gun

He was always after good folks and he kept them on the run

He shot one ev'ry morning to make his morning meal;

Let a man sass him

He was sure to feel his steel.

He kept folks in hot water,

Stole from ev'ry stage,

When he was full of liquor

He was always in a rage.

He kept tings boilin' over,

He stayed out in the brush,

When he was full of deadeye,

Other folks'ld hush

Billy was a bad man

Billy was a bad man,

Billy was a bad man

But one day he met a man

A whole lot badder

And now he's dead

And we ain't none the sadder. 


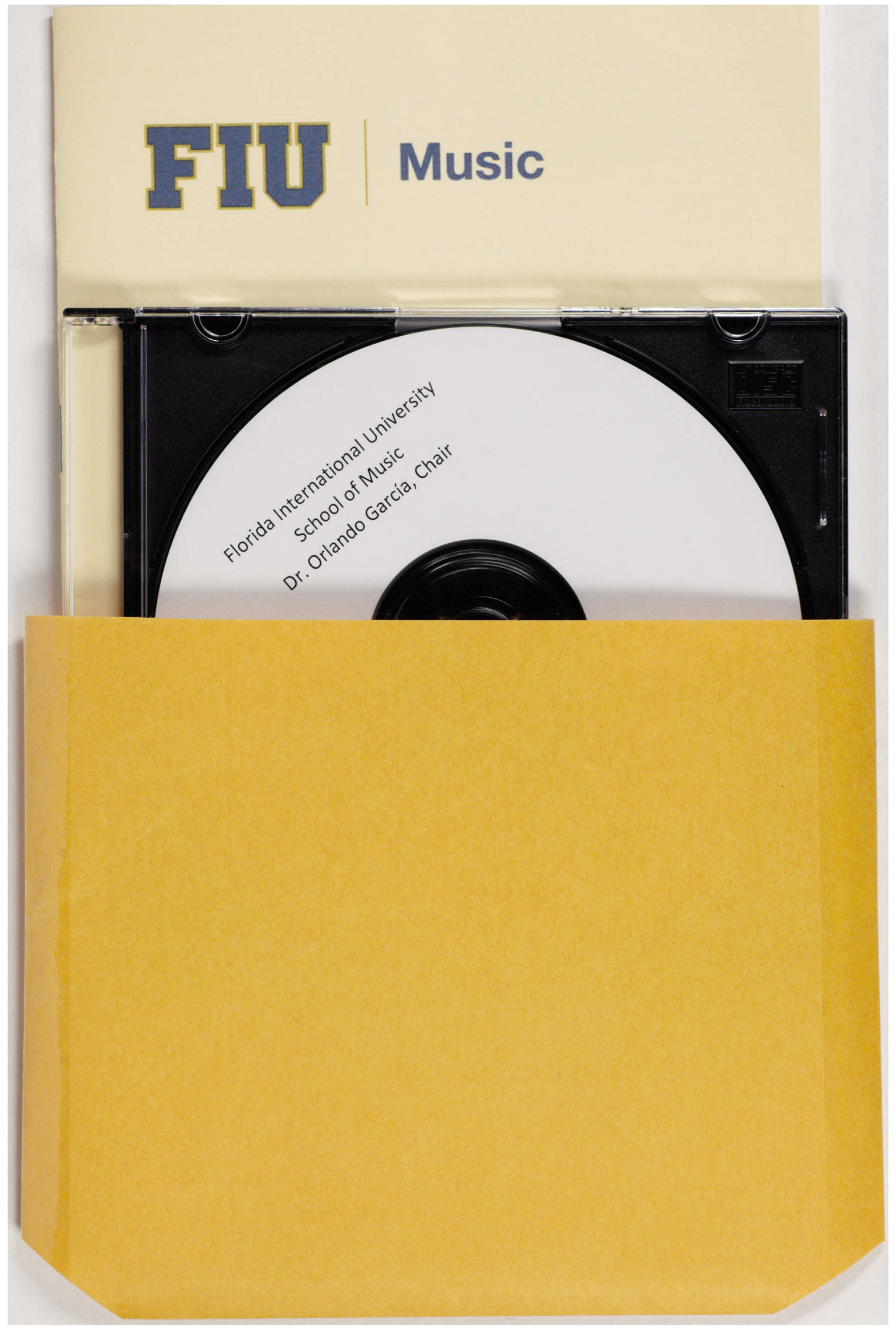

